\title{
Venice in Polish
}

\section{Literature of the Latter Half of the 16th Century and in the 17th} the Ottoman Empire, and the Centre of the Pilgrimage Culture

\section{S U M M A RY}

The aim of the study is to present at least three reasons why Old Polish writers of the latter half of the 16th century and 17th century wrote about Venice. The first one was the admiration in the nobility-ruled republican political system which emerged in the Republic of Venice, and which was considered as an attractive model by Old Polish thinkers and writers. They, e.g. Palczowski, Górnicki, and Wolan, expressed their convictions in their treatises. The second reason was that of the struggles of Christian states with the Ottoman Empire. Venice constituted the first potential ally and often a leader of European armies intended to participate in the often-planned anti-Muslim crusades. The study references the accounts of the visions of Venice as a leader of crusades as inscribed in the exhortation-related literature. The third reason was the perception of Venice as a safe port for pilgrims travelling to the Holy Land and, more broadly, to the territory of the Ottoman state via the sea. Its image emerged from the accounts of Old Polish pilgrims, travellers, and escaped slaves.

\section{Keywords}

Republic of Venice, crusade, pilgrimages to the Holy Land, political system of the Republic of Venice, 16th and 17th-century Polish literature, Venetian-Turkish rivalry, Polish-Italian cultural contacts 
The image of Venice in Old Polish literature constitutes an extensive and significant part of Polish-Italian relations which have developed over many centuries. Realising the importance of those relations, researchers such as Henryk Barycz, Alojzy Sajkowski, and Tadeusz Ulewicz eagerly described panoramas approximating individual stages in the development of the countries' bilateral literary and cultural contacts. Polish-Italian relations had several kinds of foundations: confessional (mind you, Rome was the capital of the State of the Church, which was the destination of various pilgrimages in celebration of consecutive major anniversaries), cultural (Italy was the cradle of the Renaissance; Florence and Rome were visited in the 15th century by, e.g. Gregory of Sanok and Jan Długosz), ${ }^{2}$ dynastic (queen Bona Sforza, Duchess of Bari and Rossario, was the daughter of Gian Geleazzo Sforza, Duke of Milan), ${ }^{3}$ academic (Polish youth travelled, especially in the 16th century, to study in Italy choosing Padua, Bologna, and Rome), trade, and finances. Florence, Milan, Genoa, and Venice, "called 'the second Byzantium,"' were admired by visitors. ${ }^{4}$

Both Venice itself as a municipal centre and the Venice Republic as a state which included Padua, key for the history of Renaissance sciences in Poland, and the local university, played a fundamental role in the shaping of Polish awareness in sciences (philology, philosophy, etc.), political notions, trade contacts, the fulfilment of publishing initiatives, urban culture (visits, celebrations), and theatre (musical ones in particular). Additionally, they fulfilled the leading role in the struggles against the Sublime Porte, ${ }^{5}$ and, finally, they had a near monopoly in pilgrim traffic within the route leading to the Holy Land. ${ }^{6}$ Overview studies on the significance of Venice in culture have been written by, e.g. Mieczysław Brahmer, Stanisław Kot, Bronisław Biliński, and Grzegorz Franczak.?

${ }^{1}$ Henryk Barycz, Spojrzenia w przeszłość polsko-włoska (Wrocław: Zakład Narodowy Imienia Ossolińskich - Wydawnictwo, 1965); Alojzy Sajkowski, Włoskie przygody Polaków. Wiek XVI-XVIII (Warsaw: Państwowy Instytut Wydawniczy, 1973); Tadeusz Ulewicz, "Związki kulturalno-literackie Polski z Włochami w wiekach średnich i renesansie. Ogólny szkic panoramiczny," in Literatura staropolska w kontekście europejskim (Związki i analogie). Materiaty konferencji naukowej poświęconej zagadnieniom komparatystyki (27-29 X 1975), edited by Teresa Michałowska and Jan Ślaski (Wrocław: Zakład Narodowy Imienia Ossolińskich - Wydawnictwo Polskiej Akademii Nauk, 1977), 21-67; idem, Iter Romano-Italicum Polonorum, czyli o zwiazkach umysłowo-kulturalnych Polski z Włochami w wiekach średnich i renesansie (Krakow: Universitas, 1999).

${ }^{2}$ Joanna Olkiewicz, Kallimach doświadczony (Warsaw: Ludowa Spółdzielnia Wydawnicza, 1981); Grzegorz Franczak, “Hierosolymitanorum processio. I pellegrini polacchi tra Venezia e Dalmazia," in La Dalmazia nelle relazioni di viaggiatori e pellegrini da Venezia tra Quatroe Seicento, edited by Sante Graciotti (Rome: Bardi Editore, 2009), 239.

${ }^{3}$ Maria Bogucka, Bona Sforza (Wrocław: Zakład Narodowy Imienia Ossolińskich Wydawnictwo, 1998), 24-28.

${ }^{4}$ Ibid., 9 .

${ }^{5}$ See Mieczysław Brahmer, Powinowactwa polsko-włoskie. Z dziejów wzajemnych stosunków kulturalnych (Warsaw: PWN, 1980), 206-211 (ch. XIII. “Pod urokiem Wenecji”).

${ }^{6}$ Danuta Quirini-Popławska, "Pobyt w Wenecji pielgrzymów udających się do Ziemi Świętej w XIV i XV wieku," in idem, Italia Mia. Studia z dziejów Italii i powiązań polsko-włoskich w późnym Średniowieczu i Renesansie (Krakow, 2016), 163-166.

${ }^{7}$ Brahmer, Powinowactwa polsko-włoskie..., 206-211; Stanisław Kot, Venezia vista dai Polacchi nel corso dei secoli, (Venezia: Dr. Francesco Montuoro - Editore, 1947); Bronisław Biliński, 
Padua, located near Venice, was the destination chosen by students who studied in Italy in the Renaissance. Visitors to Padua included writers, such as Klemens Janicjusz, Marcin Kromer, Stanisław Orzechowski, Szymon Marycjusz z Pilzna, Jan Kochanowski, Andrzej Patrycy Nidecki, Stanisław Warszewicki, Stanisław Iłowski, and Łukasz Górnicki. Jan Zamoyski was the chancellor of Paduan legists, it was there that Wawrzyniec Goślicki published in 1568 De optimo senatore, and Paweł Palczowski in his work Status Venetorum analysed the Venetian political system'. People of letters also visited Venice and mentioned it in their works. ${ }^{10}$

In the poem "Włoskie miasta co przedniejsze" [The More Superb Italian Cities] included in Pielgrzym włoski albo krótkie Rzymu i przedniejszych miast włoskich opisanie published in 1614, Stanisław Grochowski, offering a descriptive synthesis of Venice, indicated its three main features: wealth, a close relationship with the sea, and the patronage of St. Mark; he wrote: "Wenecyja: bogata, morzem otoczona / K temu Marka ś[więtego] ma w niebie patrona"11 [Venice: rich, surrounded by the sea / Additionally, it has St. Mark as its patron in heaven].

Various guides and descriptions of Venice indicate how Poles were fascinated with the city. Such descriptions were written by Andrzej Wargocki, the interpreter in the travels of Breidenbach and Krzysztof "the Orphan" Radziwiłł, which he published as a kind of appendix to the 1610 treatise $O$ Rzymie pogańskim i chrześcijańskim ksiag dwoje. The description covered: information that Venetians originated from Trojans, a detailed description of St. Mark's Church (marble floors, walls covered with marble slabs, painted ceiling, pillars, five doors and their decorations, the roof, brass cast horses from Roman times, a painting of St. Mark, the choir, the altar, the ciborium, paintings of St. Dominic and St. Francis located in

\footnotetext{
“Viaggiatori polacchi a Venezia nei secoli XVII-XIX (saggio preliminare: esempi ed osservazioni generali)," in Venezia e la Polonia nei secoli dal XVI al XIX, a cura di Luigi Cini (Venezia-Roma: Istituto per la Collaborazione Culturale, 1968), 341-417; idem, "Venezia nelle peregrinazioni polacche del Cinquecento e lo «Sposalizio del Mare» di Giovanni Siemuszowski (1565)," in Italia, Venezia e Polonia tra umanesimo e rinascimento, a cura di Mieczysław Brahmer (Wrocław, 1967), 233-290; Franczak, Hierosolymitanorum processio..., 235-254.

${ }^{8}$ See, e.g. Danuta Quirini-Popławska, “Podróże polskich duchownych do Padwy w XV i XVI wieku; wstępne rozpoznanie," in Itinera clericorum. Kulturotwórcze i religijne aspekty podróży duchownych, edited by Danuta Quirini-Popławska and Łukasz Burkiewicz (Krakow: Wydawnictwo Naukowe Akademii Ignatianum, 2014), 249. This includes numerous details regarding the studies of Poles in Padua and further subject literature.

${ }^{9}$ See Kot, Venezia vista dai Polacchi..., 22; Karol Koranyi, “La costituzione de Venezia nel pensiero politico della Polonia," in Italia, Venezia e Polonia. Tra umanesimo e rinascimento, a cura di Mieczesław Brahmer (Wrocław: Zakład Narodowy Imienia Ossolińskich Wydawnictwo Polskiej Akademii Nauk, 1967), 206-214; Ulewicz, Iter Romano-Italicum Polonorum..., 187-203.

${ }^{10}$ See Biliński, Venezia nelle peregrinazioni..., 254-256. The researcher indicated references in the works by Janicjusz and Kochanowski.

${ }^{11}$ Stanisław Grochowski, Włoskie miasta co przedniejsze (Krakow: [Mikołaj Lob], 1599); [reprinted in:] idem, Rzym nowy szczęśliwszy nad stary (Krakow: [?], 1610), issue $\mathrm{B}_{2 \mathrm{v}}$; [reprinted in:] Pielgrzym włoski albo krótkie Rzymu i miast przedniejszych włoskich opisanie. Teraz nowo z włoskiego na polski jezyk przełożone. Przez Franciszka Cesariusa. Przydane są od tegoż drogi i gościńce cudzoziemskie, rachując wszędy dalekość ich na mile własne każdego Państwa, przy tym też wiadomość niemieckiej $i$ włoskiej monety (Krakow: Dziedzice Jakuba Siebeneichera, 1614), p. 41v. [Unless indicated otherwise, quotations in English were translated from Polish]
} 
the sacristy, the contents of the treasury), the nearby tower, an enumeration of buildings (churches, monasteries, hospitals, etc.) and streets, the ceremony of the Doge of Venice tossing a ring into the sea marking the beginning of Venice's rule over the Adriatic, the organisation of the rule, the structure of the treasury (including taxes), a description of the Armoury, the craftsmen working and the war gear gathered there, and the war ships moored in the port. The author held the military potential of the Republic of Venice in high esteem. ${ }^{12}$

A synthetic presentation of Venice both as a republic/state and a city, with descriptions of its landmark buildings, which for their appearance and the specificity of the institutions evoked respect or even admiration for their systemic solutions, can be found in an account of an educational journey completed by Prince Janusz Wiśniowiecki in 1613-1618. The visit to Venice occurred in the summer of 1614 :

\footnotetext{
Forum Julijuszowe, Gryzonowie kędy

I możności weneckiej widzieć forty wszędy,

Uczone Patawijum i attyckie one

Święte Muzom pasieki z Hyblu przeniesione,

Skąd na chyżej gundule po szumnej Adryi

Do dziwnej i bogatej płynie Wenecyi,

Której nie mur trojaki ani przykre skały,

Ale morskie, nawalne toczą zewsząd wały,

Znamienite Cyklady z morza wyglądają,

Parlamenty, kościoły po morzu pływają,

A na złotej kolumnie, leżąc, lew ogromny

Trzyma w nogach reiment - niezbity, [niezłomny

Prawodawca narodów, i słucha go morze

Po wschodowe daleko pałające zorze.

Tam senat i do twarzy podobne ojczystej

Na tysiącu filarach sali przeźroczystej

Widział one efory w togach opuszczonych

Przestrzegając wolności sobie poruczonych;

I Arsenał, i inne artylerskie dziwy,

I tak dawno zbierane Markowe archiwy ${ }^{13}$.
}

\author{
Anniversary forum, Some Grisons \\ And the ability to see Venetian forts \\ [everywhere, \\ The learned Patavium and the Attican one \\ The holy apiaries for the Muses moved from \\ [Hybel, \\ From the swift gondola on the rough Adria \\ Travels to the strange and rich Venice, \\ Not by walls or nasty rocks, \\ But walls of tempestuous sea surround, \\ The superb Cyclades peer out from the sea, \\ Parliaments, churches flow on the sea, \\ And on a gold column, lying, a huge lion \\ Holds a regiment in his legs - unabashed, \\ [steadfast \\ The lawmaker of nations, and the sea listens \\ [to him \\ To the far eastern sea. \\ Senate there and to a face similar to the \\ [home one \\ On a thousand pillars of a transparent hall \\ Saw those ephors in long robes \\ Observing the freedoms entrusted to them; \\ And the Armoury, and other artillery \\ [wonders, \\ And so long ago collected Mark's archives.
}

12 "Wenecja," in Andrzej Wargocki, O Rzymie pogańskim i chrześcijańskim. Księgi dwoje (Krakow: Drukarnia Łukasza Kupisza, 1610), 137-146. See Biliński, Viaggiatori polacchi a Venezia..., 356.

${ }^{13}$ Samuel Twardowski, Książe Wiśniowiecki Janusz, edited by Roman Krzywy (Warsaw: Wydawnictwo Neriton, 2014), Biblioteka Dawnej Literatury Popularnej i Okolicznościowej, vol. 13, 60-62, lines 369-388. 
Venice was only an intermediate stop during that journey. The Prince travelled all the way to Naples. The return trip occurred in 1618, and it also ran through Venice: “(...) w Lombardyją zatym / Kinie ku Wenecyi, którą wnet opuści"14 [Therefore into Lombardy / Towards Venice, which he soon shall leave].

The city itself and the organisation of the Venetian Republic, as well as its strong presence in the region, indicated the success which Venice achieved in the international arena, and the esteem it enjoyed particularly in the north and the south. It radiated northwards by dint of its attractive political model, which was similar to that which existed in the Roman republic, and which was treated as the role model for the Polish-Lithuanian Commonwealth, despite some clear differences (it was not based on any efficient administration, and the set of szlachta freedoms were closer to anarchy while Venetian nobility had to observe predefined rules). In the south and the east, it was considered as a seaborne military and trade power, competing for centuries with the Sublime Porte, and as a strong and important player in the Mediterranean and the nearby seas.

\section{Venetian Republic as an attractive political system}

The attractiveness of the Venetian model for visitors from today's Poland resulted from the fact that it was viewed as the fulfilment of the idealistic assumptions developed already in ancient Greece, Aristotle's principle of politeia, and the ideas preserved in Plato's Republic. ${ }^{15}$ Venice was considered the second Sparta. ${ }^{16}$ The model admired in szlachta's Poland was continued by the republic system of ancient Rome. The Republic of Venice - the only Italian state that avoided the dangers entailed by its political system, a feat not achieved by other Italian republics, ${ }_{1}^{17}$ which lost their independence - was considered by my Old Polish writers as a continuator of the Roman model. The Old Polish writers, and also the authors of Polish political thought, were convinced that after Rome and Venice it was the Polish-Lithuanian Commonwealth that was the third state in which the republican political system was being introduced with positive results. Venice was the role model, yet they saw similarities between it and the Commonwealth. ${ }^{18}$ The republican model of governance was described by, e.g. Donato Giannotti, a Florentine (Libro della repubblica de Viniziani, 1540), and Casparo Contarini, a Venetian (De Magistratibus et Republica Venetorum, 1543)..$^{19}$ The many visits by Poles and the extensive stays in Venice

\footnotetext{
${ }^{14}$ Ibid., 72, lines 506-507.

${ }^{15}$ Anna Grześkowiak-Krwawicz, "Admirabilis ordo. Polacy wobec mitu Wenecji," in Literatura, historia, dziedzictwo. Prace ofiarowane Profesor Teresie Kostkiewiczowej, edited by Tomasz Chachulski and A Grześkowiak-Krwawicz (Warsaw: Instytut Badań Literackich, 2006), 68.

${ }^{16}$ Claude Backvis, "Jak w XVI wieku Polacy widzieli Włochy i Włochów," in idem, Szkice o kulturze staropolskiej, selected and edited by Andrzej Biernacki (Warsaw: Państwowy Instytut Wydawniczy, 1975), 732; Anna Grześkowiak-Krwawicz, "Rzeczpospolita - pojęcie i idea w dyskursie politycznym Rzeczypospolitej Obojga Narodów. Rekonesans," Odrodzenie $i$ Reformacja w Polsce, issue 65 (2012): 27-28.

${ }^{17}$ Grześkowiak-Krwawicz, Admirabilis ordo..., 69.

${ }^{18}$ Ibid., 73.

${ }^{19}$ See ibid., 69.
} 
of people who upon returning to the Commonwealth became part of the opinion-making intellectual elite had a major impact on the propagation of the principles of the political system in the Commonwealth in the latter half of the 16th century and in the early-17th century. I am referring to not only poets and philologists, e.g. Kochanowski and Nidecki, but also to political writers: Stanisław Orzechowski ${ }^{20}$, Marcin Kromer, Wawrzyniec Goślicki, Łukasz Górnicki, Stanisław Warszewicki, Andrzej Wolan ${ }^{21}$, Paweł Palczowski, ${ }^{22}$ the author of the description of the political system of Venice, and Jan Zamoyski, ${ }^{23}$ an ardent promoter of Venice's republican achievements. ${ }^{24}$

The model enabled the reconciliation of civil liberties, the strength of the state outside it, and the equality of all people under one law. ${ }^{25}$ In Poland, the indications of the efforts to implement the model were visible in the statements by Andrzej Frycz Modrzewski when he demanded equal liability for szlachta, peasants and townspeople in terms of the penalty for murder, ${ }^{26}$ and by Orzechowski, who argued that the king was not above the law but rather was subject to it. ${ }^{27}$ Therefore, Venetian liberty also meant the attenuation of the monarch's power - it was thus understood by some members of the Commonwealth's elite and it was in that form that they wanted to implement the Venetian model. Polish political writers of the golden age praised not so much Venetian liberty as the order and discipline that existed in the state, which they wanted to transfer into the Slavic state. Orzechowski also saw much value in the solution of banishing those representatives of the Venetian state who when fulfilling their diplomatic missions would accept any gifts from a foreign ruler. He offered the example of Ermolao Barbaro (1454-1493), a translator of Aristotle's works, who accepted the Patriarchate of Aquileia from Pope Innocent VIII. Orzechowski wrote: “(...) the Venetians' severe judgement was not reduced either by the respect of his house, or the size of his mind, or emperor's reason, or papal help: he had to pay for his deed with his absence from the Venetian Republic." 28

${ }^{20}$ See fragments indicating his support for Venetian political solutions in Rozmowa około egzekucyja and Quincunx by T. Ulewicz (Iter Romano-Italicum Polonorum..., 233).

${ }^{21}$ Ibid., 234.

${ }^{22}$ Paweł Palczowski, Status Venetorum, sive Brevis tractatus de Origine et Vetustate Venetorum (Cracoviae: Officina Lazari, 1604).

${ }^{23}$ J. Zamoyski, De Senatu Romano libri duo (Venice: Jordano Zileto, 1563).

${ }^{24}$ Ibid., 234.

${ }^{25}$ Grześkowiak-Krwawicz, Admirabilis ordo..., 70.

${ }^{26}$ Adrzej Frycz Modrzewski, Ad Serenissimum et Inclytum Regem Poloniae Sigismundum Augustum Lascius sive de poena homicidi (Cracoviae: Hieronim Vietor, 1543).

27 Stanisław Orzechowski, Dyjalog abo rozmowa około egzekucyjej Polskiej Korony oraz Quincunx - the fragment was quoted in Ulewicz, Iter Romano-Italicum Polonorum..., 233. Orzechowski supported the reason behind the principle by referring to history, and he added a side note: "The Venetians hang their prince." According to the writer: "Venetian history provides that in the single sentence «For Venice to be only one!» the Venetians allowed their prince to be hanged in the square in front of St. Mark." According to Jerzy Starnawski that was a reference to a story Doge Mariano Faliero from 1355. He supposedly entered an arrangement with the plebeians against the nobility. Vide Stanisław Orzechowski, "Quincunx," in idem, Wybór pism, edited by Jerzy Starnawski (Wrocław: Zakład Narodowy Imienia Ossolińskich - Wydawnictwo, 1972), BN I 210, 477-478.

${ }^{28}$ Stanisław Orzechowski, "Quincunx," 473. 
The education received by later Polish elites in Padua and student visits to Venice, and the admiration they had for the republican system of the Republic of Venice were reflected in the treatises and dialogues of Polish writers of the Renaissance and the early Baroque. I am referring to the writings by Paweł Palczowski, Łukasz Górnicki, Andrzej Wolan, Stanisław Orzechowski, Jan Zamoyski, and Stanisław Warszewicki.

Palczowski was the author of a work which offered a comprehensive description of Venice's political system. ${ }^{29}$ The eight-chapter treatise discussed the origins of Venetians, described the territories which belonged to the state, including its seaward colonies (it was a kind of a chorography of the lands which belonged to Venice and the city) and its wealth; it discussed the institutions included in the organisational structure of the Republic ("Venetiae dependet principaliter a tribus magistratibus, nimium Concilio magno, Ordine Senatorio, Principe ${ }^{\prime 30}$ ); it also discussed the income and expenditures of the Venetian state, offered a specification of the war gear and principles of financing wars ("nervus belli est pecunia" ${ }^{31}$ ), and provided examples of ancient leaders; it also discussed wartime successes, the need for bravery and good luck, and Venice's neighbouring states. The work included references to the more recent history of Venice: to people and events, wars in particular.

Wolan's fifteen-chapter-long treatise drew inspiration from a work by Contarini; the author following the findings of his compatriot predecessors treating those as a common good. ${ }^{32}$ The initial five chapters were used to define the essence of liberty in the historical, philosophical (e.g. Plato, Aristotle, and Cicero), and social contexts. Chapters four through nine were used to analyse the relationships between law and liberty in the Commonwealth, while the final set of chapters (from the ninth to the fifteenth) raised the need to reform the legislature and judicial system (including the topics of unequal application of the penalty for murder, and szlachta excesses). ${ }^{33}$

In Rozmowa Polaka z Włochem o wolnościach i prawach polskich, Górnicki discussed the issue of the election of the ruler still remembering the election of Stefan Batory. He considered the Venetian model, which drew inspiration from its Roman predecessor, as a model worth emulating. He argued that an election inside a closed room instead of in the field enabled a community to maintain its control over the elected official. He believed that the election of a ruler should not occur under the pressure of gifts offered by candidates to rulers-elect, nor should it be the outcome of a ruse. Górnicki discussed the notion of liberty and how it differed from wilfulness, which the Italian (one of the interlocutors) condemned. The interlocutors were also interested in

\footnotetext{
${ }^{29}$ Ulewicz, Iter Romano-Italicum Polonorum..., 234; Biliński, Viaggiatori polacchi a Venezia nei secoli XVII-XIX (saggio preliminare: esempi ed osservazioni generali), 354-355.

${ }^{30}$ Paweł Palczowski, Status Venetorum (Cracoviae: Officina Lazari, 1605), vol. 20.

${ }^{31}$ Ibid., vol. 38.

${ }^{32}$ Grześkowiak-Krwawicz, Admirabilis ordo..., 71, 74-75; Roman Mazurkiewicz, "Wstęp," in Andrzej Wolan, De liberatate politica sive civili * O wolności Rzeczypospolitej albo ślacheckiej (tłumaczenie Stanistawa Dubingowicza), edited by Maciej Eder and Roman Mazurkiewicz, volume's academic editor Wacław Uruszczak (Warsaw: Wydawnictwo Neriton, 2010), 42, 47.

${ }^{33}$ Vide Mazurkiewicz, Wstęp, 28-30.
} 
how the Sejm functioned and how laws were passed. The Italian concluded that one should proclaim such laws which would not offer any loopholes for crime or abuse. The interlocutors discussed the notion of personal security. In Poland, it was supposed to be ensured by personal guards and easy access to weapons, while in Venice by the fear of the inevitable punishment for committing a crime. The Italian argued that fear of a sentence for deed in violation of the law was much better than wilfulness. Gornicki discussed the judiciary to some extent. He presented the absurd nature of the solutions in place in the Commonwealth which ensured impunity for the wealthy and perjurers. The Italian considered Sejm's royal court as being ineffective. He concluded that in practice the judiciary in Poland was broken. The Pole boasted that in his state a person could be sent to jail only after a sentence of guilt was passed. The Italian believed that confinement should also be considered a preventive measure used for preventing criminals from committing further crimes. He offered the examples of counterfeiting money and murder. The Italian interlocutor also condemned marriage between close relatives, and he accused Poles of polygamy and the practice of exchanging wives. He saw that as an outcome of the suspension of secular jurisdiction of sentences issued by religious courts. The impairment of the judiciary led in Poland to a spike in crime rates. The Italian accused Poles not only of indifference regarding the fates of those captured into Tatar-Turkish captivity, but also regarding the roguery occurring in households in the form of property disputes ending in relatives murdering each other. The Italian also accused Poles of excess in clothing, the fact of drawing inspiration from fashion while ignoring other good habits, e.g. that of drinking, emulating the Turkish way, water instead of alcoholic beverages: "Ci, którzy u was po turecku chodzą, wino niż wody wolą"34 [Those who walk in your country the Turkish way, prefer water to wine]. Through the Italian's lips, the writer also condemned visits to Italian hot springs for improving one's health, and so-called educational trips, in which Venice was often the destination. He believed that szlachta youth should learn the art of war and serve its homeland in borderland garrisons, defending it against the Tatars. Italy should, then, be visited for study by people with considerable experience, who would be able to transfer the good traits onto the Polish soil. That was the way in which the Republic of Venice achieved its praiseworthy political status: "Bo co owo młódź ślecie do Włoch dla tańców, dla lutnie, nie przyniosą owi z sobą tego, co by Koronie było zdrowo, ale to przyniosą, czego nie umieć zdrowiej było"35 [What is the merit sending your youth to Italy to dance, to play, as they will not bring with them that which would make the Crown healthy, instead they bring that which cannot make it healthier]. The Italian also defined what a proclaimed law should be - that it should be based on natural law. The Pole was apprehensive about excessively strict law, which would result in many instances of banishments or defections to

\footnotetext{
${ }^{34}$ Łukasz Górnicki, "Rozmowa Polaka z Włochem o wolnościach i prawach polskich,” in idem, Pisma, edited by Roman Pollak, vol. 2 (Warsaw: Państwowy Instytut Wydawniczy, 1961), 378.

${ }^{35}$ Ibid., 380.
} 
hostile neighbouring countries. The Italian argued that it was Venice that was closer to the Porte, and despite its severe laws no one was fleeing it. He also discussed the Italian judiciary, in which murder was punishable by death unless it was committed in self-defence or in defence of defenceless people (women). He rebuked the Polish penalty for murder which consisted of paying a fine for every head killed, i.e. the so-called główszczyzna. The dialogue included a criticism of the system of the Polish-Lithuanian Commonwealth in the form of a comparison of its legal solutions to those on which the Venetian democracy was founded.

The treatise Droga do zupetnej wolności also raised the issue of the operation of courts in the Commonwealth. The opinion journalist expressed his support for courts operating in a continual manner, and he criticised the time-limited six-week royal court, which issued sentences only every other year. He compared that situation to pilgrims travelling from Venice to the Holy Land who would put people who knew how to navigate the water from their big ship into a small boat and would only invite them back when a storm would come nigh. In following the Venetian model, the writer postulated that senators and deputies should fulfil their obligations year-round living throughout that time by the king. He discussed the organisation of state bodies, emulating their Venetian counterparts, in the judiciary. He considered the custom of voting through apella as a method worth emulating, though he appreciated even more the Venetian method of ballot voting, i.e. using canvas balls; he described the system in detail. ${ }^{36}$ The voting using balls and coloured boxes was supposed to support the freedom of decision as it guaranteed the confidentiality of the process. It was also supposed to eliminate the never-ending displays of oratory skills by deputies, who often formulated their positions matching their fellow politicians and not speaking in reflection of their own conscience. That is because the legal system should be based on strict punishment for criminal deeds and rewarding for merits. According to the Venetian model, the power of a ruler was supposed to be complemented by a twelve-person senate. Offices were supposed to be term-based: the upper office was supposed to have a term of eighteen months, and twelve months in the case of senators. The writer opposed the filling of offices for life. As Górnicki argued, the high quality of Venetian solutions was proven by their long history. He did not conceal the fact that he was using Contarini's work, adapting his solutions to match the Polish reality. He expanded on the notion of the application of public prosecution. The topic also appeared in Rozmowa. The council of twelve was also to operate as a public prosecutor while the king was supposed to judge. The writer argued in favour of an independent financing of the members of the senate to avoid bribery. The king and the senate were supposed to be monitored by a council consisting of 16 people. Górnicki also discussed the defence system, which was supposed to be based on a continuous presence of the army at the borders and in castles erected there. He opposed the argument that "«nic Polakom po mocnych zamkach, Polak polem stoi i w polu się bije, nie

${ }^{36}$ See Górnicki, “Droga do zupełnej wolności,” in idem, Pisma, 494-495. 
za murem (...)»"37 [Poles should have no interest in strong castles, Poles have many fields and they fight in the fields, not behind walls]. He argued that both Sparta and Venice lasted so long because of their fortifications in the form of seas. Górnicki saw the trade of abducted Commonwealth citizens as an outcome of the lack of fortifications: "(...) jeśli naszej braciej, naszych sióstr, ciotek i innych powinnych, które w Carogrodzie na rynku przedają jako ine bydło, boli krzywda?"38 [if our brothers, our sisters, aunts and other relatives who in Tsar-gord in the market square are sold like cattle, feel the harm?] According to him the remedy for that situation would have been the maintenance of a continuously sitting Sejm and an army at the borders. In emulating the Venetian model, he also argued for establishing a national treasury and a tax collection system. He believed that fiscal encumbrance should be permanent and low. He argued that orphans and their property, in order to avoid abuses in the form of exploitation and harm, should be cared for by the state, i.e. the council of the twelve to be precise. The advantage of the Venetian model over the legal system of the Commonwealth also consisted of the fact that the Venetian system of governance underwent modifications if needed, while the organisational structure of the rule in the Commonwealth was unalterable, which made it increasingly inefficient and incompetent. ${ }^{39}$

Therefore, even though people in the Commonwealth in the 16th century admired the political system of Venice, none of its solutions were transferred into the Polish legal system. Most were content with superficial analogies, and slogans, especially about freedom and the functioning of democratic parliamentary institutions, which in practice meant close to nothing. Finally, most feared Venetian discipline and consistency in enforcing the law, including punishments. Szlachta's freedom meant wilfulness; Venice offered rich sons of magnates a chance to use it during their foreign educational travels.

\section{Venice as the leader in the fight against the Ottoman Empire}

The Republic of Venice was present in the struggles with the Ottoman Porte in 1443-1444. Before that it maintained regular relations with the sultan, considering the benefit of being able to conduct unhindered trade. Its participation in the anti-Islamic crusade announced by Pope Eugene IV in January 1443 consisted of sending galleys, 12 of which reached, together with the pope's galleys, to the shores of the Dardanelles. They prevented the 40,000-strong Turkish army from crossing onto the Balkan Peninsula. Sultan Murad II did, however, cross the Bosporus at Rumelihisarı on Genoan ships around 20 October 1444 . Soon afterwards, on 10 November, the sultan's army defeated Christian armies at Varna. ${ }^{40}$ The Ottoman Porte

\footnotetext{
${ }^{37}$ Ibid., 516.

${ }^{38}$ Ibid., 518.

${ }^{39}$ See also Stanisław Tarnowski, Pisarze polityczni XVI wieku, introduction and notes Bogdan Szlachta (Krakow: Ośrodek Myśli Politycznej, Księgarnia Akademicka 2000), 727-745.

${ }^{40}$ See Danuta Quirini-Popławska, "Republika Wenecka wobec akcji antytureckiej w latach 1440-1444 na tle sytuacji politycznej w Europie," in idem, Italia mia..., 147-160.
} 
openly stood in opposition to the Republic of Venice only after the erection of Rumelian Castle on the Bosporus in 1452, when Venetian ships ignored a demand to submit to Turkish inspection, and as a result three ships were fired upon, two fled and one sank; Turks executed the ship's survivors and impaled the captain. ${ }^{11}$ Venetians sent a fleet of 15 galleys and two transport ships towards Constantinople, yet they did not reach the fight in time. ${ }^{42}$ Neither did they engage sufficiently in the crusade organised by Pope Pius II in 1464. When the Venetian fleet reached Ancona, the pope died, so the ships returned to Venice..$^{43}$ In 1470, Negroponte (Chalcis), the capital of the largest and the most important Venetian colony located in Euboea, fell into Turkish hands. ${ }^{44}$ In 1473 , Venetians were able to defend the Albanian city of Scutari from the Turks. The struggles with the Ottoman Empire continued in the following years. Venice lost the island of Lemnos and its Krujë castle in Albania, and most of the lands in the country, as well as lands in continental Greece; at the beginning of 1480, Turks seized Otranto in Apulia. In 1479, it signed a treatise with Mehmed II, which was confirmed two years later by Bayezid II, his successor. ${ }^{45}$ The rule of the sultan and his successor meant 42 years of peace for Venice, with the exception of 1499-1503 when the emperor felt threatened. ${ }^{46}$ In the course of their struggles with Suleiman the Magnificent, Venetians were able to defend Corfu in 1537, yet they lost numerous islands near the Peloponnese. Venice did not receive support either from other Italian states, France or the Empire. The anti-Turkish alliance between the emperor, the pope and Venice signed in 1538 ended in a fiasco at Preveza near Epirus and the signing of an unfavourable peace treaty in 1540. Andrea Doria, a Genoan, contributed to the defeat. ${ }^{47}$ Peace lasted until 1565 when the Turks attacked (unsuccessfully) Malta. ${ }^{48}$ The Venetians' attempt a day before the Turkish attack on Cyprus to gather a broad coalition against the Ottoman Porte ended in a fiasco. Pope Pius V and King Philip II of Spain declared aid. The failed expedition of 205 allied ships did not reach even the island, which Turks seized in 1570 conducting massacres in Nicosia and Famagusta. ${ }^{49}$ 1571 brought another maritime victory of the Holy League, which consisted of Venice, the State of the Church, and the Kingdom of Spain..$^{50}$

For the anti-Turkish propaganda to achieve the results intended by their authors, they had to not only consider the political reality, but also be written in Latin. In the initial period, Orzechowski's De bello adversas Turcas suscipiendo $(1543, \mathrm{~A} 4 \mathrm{v})$ and Turcica secunda $\left(1544\right.$, book $\left.\mathrm{C}_{7 \mathrm{v}}\right)$ were the most

${ }^{41}$ John J. Norwich, Historia Wenecji, trans. Jakub Bartoszewicz, 2nd edition (Warsaw: Wydawnicto $A B, 2015), 320$.

${ }^{42}$ Ibid., 321-325.

${ }^{43}$ Ibid., 340-341.

${ }^{44}$ Ibid., 345-346.

${ }^{45}$ Ibid., 348-353.

${ }^{46}$ Ibid., 438.

${ }^{47}$ Ibid., 451-452.

${ }^{48}$ Ibid., 462-463.

${ }^{49}$ Ibid., 470-476.

${ }^{50}$ Ibid., 476-483. 
noteworthy (after many years, translated into Polish with the intention to enable general access to the principles of the anti-Turkish league in the country); in them, Venice was referenced only as one of the Italian states which might participate in the league intended to conduct a total land and maritime war against the Turks. ${ }^{51}$ In a similar manner, Venice's participation in the crusade/league was depicted by Bartłomiej Georgiewicz, a former Turkish slave and later an anti-Turkish writer who published his exhortations throughout Europe in Latin, German, Italian, and Polish: "If Venetians and the Portugese gathered their sea army, Angles, Poles and other princes added their knights, and especially if that Emperor advised, Soliman would no longer oppose Karolus than Darius opposed Alexander, than Xerxes opposed Themistocles, or than Antiochus opposed Judah Maccabee."52

Calls directed towards the Republic of Venice to participate in a general Christian anti-Turkish league were not uncommon even later in Polish anti-Turkish literature. Those can be found in period anti-Turkish literature, e.g. in works by Maciej Stryjkowski, Józef Wereszczyński, and Wawrzyniec Chlebowski. They appeared on a regular basis at least between 1550 and $1650 .{ }^{53}$ The most significant work, which painted a panoramic view of the relations between the Republic of Venice and the Ottoman Porte, was Krzysztof Warszewicki's narrative poem Wenecyja first released in 1572, and later in 1587. Warszewicki's work was later used by various poets who raised the anti-Turkish theme, e.g. Józef Wereszczyński, Marcin Paszkowski, and Wawrzyniec Chlebowski. ${ }^{54}$

When writing the Wenecyja narrative poem, Krzysztof Warszewicki applied the convention of a lament uttered by personified Venice. The historically-viewed relations between the Republic of Venice and the Ottoman Porte were the work's main theme. The history of Turkey's power - described in the form of a presentation of consecutive rulers of the vigorously unfolding empire - constituted another major component ${ }^{55}$.

The author found reason for the lament, and an encouragement to engage in a fight against the enemy threatening the Christian world in a recent seizing of Cyprus (in 1570) by the Turks and the cruelty they inflicted in

${ }^{51}$ Stanisław Orzechowski, Oksza na Turka, trans. Jan Januszowski (Krakow: Drukarnia Łazarzowa, 1590), 12, 128.

${ }^{52}$ Bartłomiej Georgiewicz, Rozmowa z Turczynem o wierze krześcijańskiej i o tajności Trójce Świętej, która w Alkoranie stoi napisana (Krakow: Helena Unglerowa, 1548), book $\mathrm{C}_{1}$

${ }_{53}$ More on anti-Turkish literature: Juliusz Nowak-Dłużewski, Okolicznościowa poezja polityczna w Polsce. Zygmunt III (Warsaw: Instytut Wydawniczy PAX, 1971), 233-310; Piotr Trafiłowski, "Imago Turci”. Studium z dziejów komunikacji społecznej w dawnej Polsce (1453-1572) (Lublin: Wydawnictwo Uniwersytetu Marii Curie-Skłodowskiej, 2013), 119-235; Wołodymyr Pyłypenko, W obliczu wroga. Polska literatura antyturecka od połowy XVI do połowy XVII wieku (Oświęcim: Napoleon V, 2016), 93-105, 165-166; Michał Kuran, "Anti-Turkish literature in the Polish-Lithuanian Commonwealth, 1575-1733," in Christian-Muslim Relations. A Bibliographical History, Volume 14: Central and Eastern Europe (1700-1800), edited by Davide Thomas, John A. Chesworth (Leiden-Boston: Brull, 2020), 471-493.

${ }^{54}$ Teodor Wierzbowski, "Przedmowa," in Wenecyja. Poemat historyczno-polityczny z końca XVI wieku, published by Teodor Wierzbowski (Warsaw: Drukarnia Józefa Bergera, 1886), XXXIIXLI; Nowak-Dłużewski, Okolicznościowa poezja polityczna w Polsce..., 239, 241-242, 248-250.

${ }^{55}$ The work was discussed by, e.g. Pyłypenko, Wobliczu wroga..., 98-100. 
Nicosia and Famagusta. ${ }^{56}$ According to him, an opportunity for a counter-attack was a recent victory in a maritime battle at Lepanto. In its first edition, the work was ascribed to Walenty Dembiński, Chancellor of Poland. The second edition was ascribed to Andrzej Tęczyński, a Krakow voivode. As the author stated in the first dedication, the aim of the narrative poem was to familiarise szlachta readers with the history of the struggles of the Republic of Venice with the Porte, and to present the consecutive stages of the growth of the Ottoman dominance. Using a relatable example (analogies in terms of the political system), the szlachta was supposed to learn how to prevent the calamity with which Venice was struggling. The writer depicted the Porte as an untrustworthy opponent interested in their expansion and using schemes for momentary gains (that, in fact, was a common motif in anti-Turkish literature). He saw the alliance, which should have bound Christian states, as obliged to stand in solidarity in defence of Venice. The passage read: "A zwłaszcza z strony tego spólnego nieprzyjaciela imienia chrześcijańskiego, tureckiego okrutnika, który przykładem przodków swoich, nie dzierżąc nikomu nigdy ni wiary, ni przymierza, jedno póki mu się zda albo póki mu go potrzeba, targnął się na weneckie państwo bez żadnej przyczyny mimo przysięgę i przymierze dane ${ }^{\prime \prime 57}$ [And especially from the common enemy to the Christian name, the Turkish brute, who in following the examples of his predecessors, not ever observing anyone's faith or alliance, only as long as it is useful or necessary for him, attacked the Venetian state without any reason despite the oath it gave and alliance it entered]. Warszewicki considered the seizing of Cyprus as a prelude to a Turkish march to capture Italian lands.

The personified Venice in the initial rhymed part of the speech instructed the recipients identifying the factors which led the state to its downfall. According to him, the main ones included a lack of solidarity or agreement between the members of the Christian side, which was a result of their disregard for the Turkish threat. Therefore, he called for a united cooperation in fighting the enemy, who has been a natural enemy for generations ("z przodków, z przyrodzenia" [ancestor after ancestor, by birth] - book Bv, line 43), who had hostility towards all Christians in their blood, which Venice had proven with its extensive experiences. The speaker also warned readers against Turkish ruthlessness and a practice of establishing favourable tactical alliances only to break them once they were no longer beneficial. The Porte seemed an unreliable partner, a fact about which Venice was trying to warn readers. The self-presentation of the speaking persona is worth considering - it expressed a praise of Venice as a city and a state:

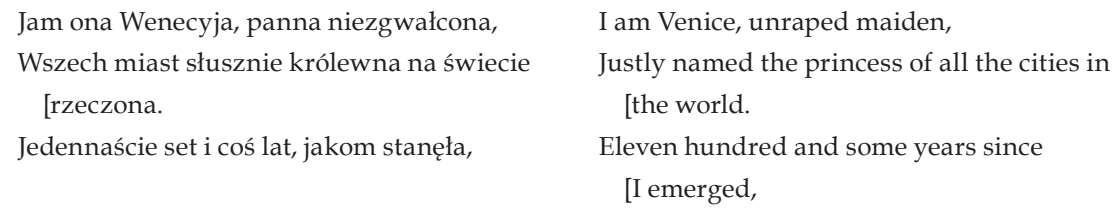

${ }^{56}$ Norwich, Historia Wenecji, 477-478.

${ }^{57}$ [Krzysztof Warszewicki], Wenecyja, [Krakow]: Mateusz Siebeneicher, 1572, sheet $\mathrm{A}_{3} \mathrm{v}$. 
Kiedy ono Attyle sroga broń słynęła.

Jednym dziwem na świecie mnie też [poczytają;

Ci sami lekceważą, co mię nie widają.

Mam to zdawna, że wiary bronię i Kościoła,

Żem włoskich państw ozdobą, żem wszytkich cnót szkoła.

Były już łupem nieraz miasta, państwa [drugie;

Wiodąc ziemią i morzem z różnymi narody

Wojny częstokroć wielkie o miłe swobody,

Wszakże nigdy nie z chęci, ale przymuszona,

Nienawiścią ze wszech stron będąc

[ogarniona $^{58}$.
When Attila's severe weapon was known.

I am also considered a wonder of the world;

I am scorned by those have not seen me.

I have had it long, that I defend faith and the [Church,

That I am a gem of Italian states, that I am the seat of all virtues.

Other cities and states have been looted [before;

Waging land and sea wars with other nations Often grand wars for pleasant liberties,

But never for wanton, forced rather,

By hatred surrounded from every side.

The self-praise covered the long history of the city-state, its uniqueness - it seemed a new wonder of the world, which was proven by people visiting the capital of the Republic; and its virgin state, i.e. that it had never been captured by enemies. It wished to play the role of a defender of Christian faith in the international arena, and considering its organisation it perceived itself as a leader in promoting social attitudes which increased social welfare. The self-praise also covered the city-state's perfection, which was reflected in its military strength, a point which the Venetian army was not able to prove either on land or, especially, at sea. It stressed that it had led just wars, that is in defence of its land and non-material values (i.e. the freedom of its republic), and that persevered despite the hatred of its enemies (i.e. competing with other Italian cities, and the Ottoman Empire). The Porte in particular, according to the persona, wished to deprive Venice of its seaward colonies and its freedom viewed as a political achievement.

The core of the argument was a historical narratio which presented the struggles of the Republic of Venice with the Ottoman Porte, also depicting the consecutive stages of the spread of the Turkish dominance under the rule of consecutive sultans. The account of the fall of Cyprus and especially the fights for Nicosia and Famagusta, which ended in massacres of their inhabitants, constituted a major plot. When the Turks were capturing the first of the port cities:

Tu kto mi da oczam łzy albo tę wymowę, Bym opłakać jako chcę, powiedzieć umiała, Jaka Bogu i ludziom krzywda się tam stała. Bo zgoła nic w nieszczęsnym mieście nie [zostało,

Co by się wszeteczeństwy, mordy nie zmazało. (...)
That who pressed tears into my eyes or the [expression,

Which would help me mourn as I wanted to, The harm done there to God and man.

As there is nothing left in the ill-fated city,

Which could erase the disgraceful deeds, the [killing.

(..)

${ }^{58}$ Ibid., book $\mathrm{B}_{3}$. 
Niesłychanej swejwolej pełno było złości,

Każdy broił co zachciał aż do żądliwości.

Ani lata, ani stan, ni rodzaj, żadnego

Wolnym nie uczyniły od gwałtu sprośnego ${ }^{59}$.
There was much of wilfulness and rage,

Everyone did what they pleased until all [desires.

Neither the years, nor the state, kind, neither

Have freed it from the foul violence.

The massacre of the inhabitants of Famagusta, whose inhabitants and defenders were promised that their lives would be spared, was depicted without any bloody details. The further details of enslavement, the discussion of the religious motivations behind the conquest conducted by Muslims, and deliberations on the ethics of war - including on dominance and the readiness to engage in fight instead of consenting to an ill peace - led to a call to undertake a joint armed mission. The speaking persona referred to the anti-Turkish league entered into by the State of the Church, Spain, and Venice on 25 May $1571 .^{60}$ As a wartime wake-up call, the personified Venice listed the benefits of such an alliance. The essence of the argument consisted of threads in the history of the Ottoman Empire: its origin and the art of conquest. ${ }^{61}$ In the account fulfilled in the form of a condemning speech, the persona mentioned the loss of Thessaloniki and Negroponte. The following argumentative part of the reasoning featured the example of Hungary as a warning for Christian states to avoid any alliances with the Porte. The reasoning was intertwined with warnings, encouragements, and discussions of knightly and religious values, laments, a diagnosis of the international situation, an evaluation of the attitudes and the actions of European states. In presenting an ill image of the enemy, Venice called for a new crusade, bearing in mind the loss of Cyprus and the attack on Friuli.

In Warszewicki's narrative poem, Venice seemed a leader in the fights against the Ottoman Porte; a player which knew the enemy the best, and who sustained significant losses to him. That gave it the moral legitimacy to formulate admonitions towards all Christian states. The defeat of enemies was supposed to mean a return of the golden age, a securing of freedoms, and avenging wrongs.

Maciej Stryjkowski condemned the loss of numerous Greek islands around the year 1570, the fratricidal fighting between Christian states, and the fact of inviting the Turks to alliances during wars waged against other Christian states in his 1575 work O wolności Korony Polskiej i Wielkiego Księstwa Litewskiego. ${ }^{62}$ He also saw the weakening of the morals of the Venetian fleet after Lepanto:

Patrzmyż i na Wenety, co wojną słynęli,

Zemdleli, co na morzu przedniejszymi byli.
We also look at Venetians, who were famed [in war,

Those who had been the greatest in the seas [weakened.

\footnotetext{
${ }^{59}$ Ibid., book [B $\left.{ }_{4}\right]$, lines 162-166, 171-174.

${ }^{60}$ Ibid., book Bv, lines 245-270.

${ }^{61}$ The historical narratio covered lines 295-890.

${ }^{62}$ See also Pyłypenko, W obliczu wroga..., 96-98.
} 
Wziął im Selim królestwo Cypr prawie obfite, Kandyją z Korfem mają, lecz prawie podbite ${ }^{63}$.
Selim took their kingdom of Cyprus abundant, They still have Candia with Corfu, though

[almost conquered.

In addition, the writer saw the diplomatic virtuosity of the Turks, who defeated one Christian state by entering an alliance with another. Such practices also harmed Venetians who eagerly had used the same strategy: “Wziąwszy z Węgry przymierze, Wenety zwojował, / Tych zaś zjednał, a włoskich miast kilko zhołdował"64 [Having established an alliance with Hungary, Venetians vanquished, / They won over those, and forced several Italian cities to pay homage].

Stryjkowski knew well that Venetians did not exploit the success they achieved at Lepanto. He knew that had they counter-attacked and could have reclaimed their recent losses. Dissent brought ruin on the recent allies. He thus depicted the course of events:

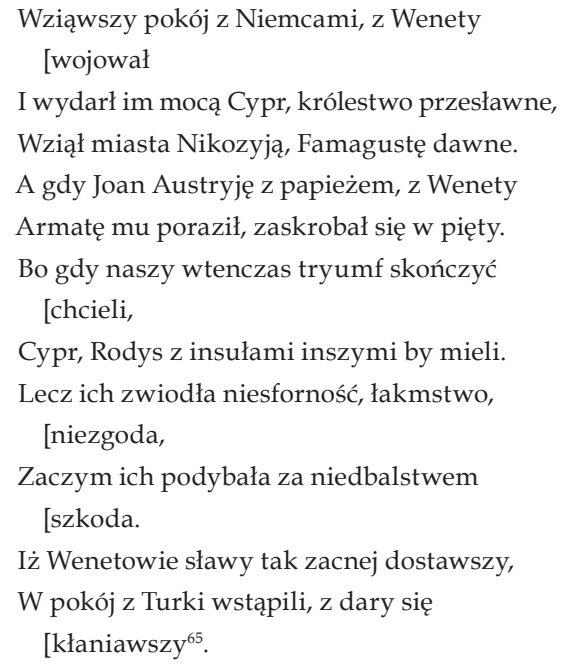

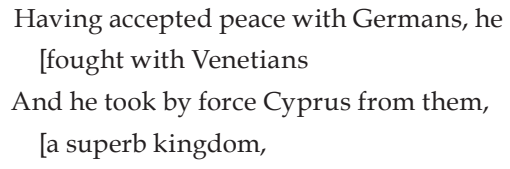

Stryjkowski referred to the events of September 1574. Yet the writer called on Polish and Lithuanian nobility to participate in the anti-Muslim campaign arguing that Italian, German and Spanish knights were waiting for them to join.

Jan Smolik wrote in the final decade of the 16th century a poem which belonged to the collective exhortation directed personally to selected European rulers (the emperor, the king of the Commonwealth, the king of Spain,

\footnotetext{
${ }^{63}$ Maciej Stryjkowski, O wolności Korony Polskiej i Wielkiego Księstwa Litewskiego, Krakow: Mikołaj Szarfenberger 1575, 15v.

${ }^{64}$ Ibid., 19. He also listed some of the recent losses incurred by the Republic of Venice: “(...) bo dwa zamki stracił, / Lecz Modon Wenetom wziął, tym sobie zapłacił” [he lost two castles, / but he took Modon from Venetians, thus paid for everything] (ibid., 35).

${ }^{65}$ Ibid., 36.
} 
the Moscow Tsar, and all Christian rulers), in which he called upon Venetians to participate in an anti-Muslim crusade. The author argued that it was intended not to achieve confessional benefits but political and economic ones. The fact of the removal of the Ottoman Porte was supposed to enable the regaining of former Greek colonies, ensure the freedom of seafaring, and help increase the profits from safe trade. A decisive victory over the Turks was supposed to bring peace and stability:

Już wy możni Weneci z swego Arsenału

(Pomścicie się też łatwie choć starego żalu).

Ruszcie śliczną armatę, galer i okrętów,

Nie bójcie się na morzu nijakich odmętów.

Bo macie Neptuna sobie przychylnego,

Fawonijus też doda wiatru pogodnego,

Który was zaprowadzi pod cypryjskie brzegi,

Tam gdzie nie zawadzą zimnych krajów śniegi.

A wy puśćcie swe działa pod cną Famagustą,

By ją też na mały czas uczynić i pustą.

Co jeśli się wam szczęśliwie powiedzie,

Niechże wasza armata pod Rodys pojedzie.

Tam też skuście, co może stateczna Bellona,

W której się rozkochała panonijska strona.

A gdy się tam ukażą wojska wasze wodne,

Bez pochyby uczynią studnie, rzeki smrodne

Przez częste trupy zbite, które i tam, i sam

Leżeć będą na pował; ulęknie się i Cham.

Wiecie, że spólne mocy łatwie pożyć mogą

Tego nieprzyjaciela, a nie inszą drogą

Może być zwyciężony. Przeto nie mieszkajcie,

Ale się co wskok do swych municyj udajcie.

Nie żałując ni czoła, ni skarbów nałożyć,

By też i Wenecyją do czasu zubożyć.

Boć się wam to w krótkości zaś może

[nagrodzić,

Kiedy wam w Dalmacyjej i w Grecyjej

[szkodzić

Nikt nie będzie. A czasu wdzięcznego pokoja

W ojczystym Arsenale będzie wisieć zbroja,

Którą teraz zaprawdę trzeba wyhecować,

Która tęga a słaba, by wiedzieć, spróbować. ${ }^{66}$
Oh, you wealthy Venetians from your Arsenal

(You shall avenge easily even the oldest of

$$
\text { [griefs). }
$$

Move your beautiful cannon, galleys and ships,

Don't be afraid of some depths in the sea.

Because you have Neptune favouring you,

Favonius shall also add fair weather wind,

Which shall lead you to Cyprus' shores,

Where no snows of cold states can reach.

And you shall release your cannons at the

[worthy Famagusta,

To empty it for a short time as well.

If you are successful,

May your cannon move to Rhodes.

There, too, seduce that which the steady

[Bellona may,

Whom the Pannonian side had beloved so.

And once your maritime armies appear there,

They will surely fill wells and rivers with the

[stench

Of the many corpses killed, which both here

[and there

Shall lie around; even Cham shall dread.

You know that joint forces shall cut down

[more easily

That enemy, who cannot be defeated

In any other way. So stop waiting,

And go to your municipalities.

Not begrudging your strength, or your wealth,

What can impoverish even Venice.

Because that may shortly reward you,

When in Dalmatia and Greece

No one will cause damage anymore. And in

[time of graceful peace

In your native Arsenal your armour shall hang,

Which now must be polished,

To test which is strong and which is weak. 
The reasoning was built around the Venetian Arsenal, which contained a strong fleet capable of success as it was favoured by gods and nature supported by the experience of Venetian sailors. The poet argued that an armoury should be kept in the Arsenal, yet only upon becoming victorious. He saw and appreciated the special nature of the Republic's maritime army.

In the later period, i.e. in the 1610s, when anti-Turkish literature published in Polish listed the potential members of an anti-Turkish league, Italian states were perceived jointly; authors regularly referred to Italians. The name Venice did not appear. The profiles of those texts indicated that the centre of gravity of such a mission consisted of conducting an expedition and struggles conducted on land. Ships were used for transporting armies when the goal was to conquer Palestine - the Holy Land. There was talk of concurrent land and maritime fighting. That was the case in Marcin Paszkowski's 1620 work Bitwy znamienite tymi czasy... z nieprzyjacioły Krzyża Świętego z roku 1620, and in his 1615 work Pobudka narodom chrześcijańskim w jedność mitości chrześcijańskiej na podniesienie wojny zgodnie przeciw nieprzyjacielowi Krzyża Świętego. During the Thirty Years' War, Venice tried to remain neutral. In 1645, the Turks began a war over Crete. The Republic was nearly alone in its defence of Candia after the fall of the fortress and the island in 1669. ${ }^{67}$ In 1684 , Venice joined the league of Christian states, who managed to permanently reclaim from the Porte some of the lands it seized in past centuries (e.g. Transylvania and Hungary) and seas (e.g. Morea, Santa Maura, and Egina). The crowning of those successes was a peace treaty signed in Carlowitz in 1699.68

\section{Venice as a transfer port for pilgrims on their way to the Holy Land}

The issue of the role of Venice as the chief centre of pilgrim traffic to and from the Holy Land in past centuries has long been the focus of Italian researchers ${ }^{69}$, and it has been raised in the studies by Polish scholars ${ }^{70}$. The major importance of Venice in the travels of pilgrims was discussed by Bronisław Biliński, Tadeusz Ulewicz, and Grzegorz Franczak. ${ }^{71}$

Jan Tarnowski, the author of the first Polish journal from his 1518 pilgrimage to the Holy Land, only referenced Venice as a place from where he set off for a voyage; he wrote: "W dniu św. Prokopa, który przypadł

\footnotetext{
${ }^{67}$ Norwich, Historia Wenecji, 554.

${ }^{68}$ Ibid., 568.

${ }^{69}$ Ugo Tucci, I servizi marittimi veneziani per il pellegrinaggio in Terrasanta nel Medioevo, Wenecja: Università di Venezia 1991; La Dalmazia nelle relazioni di viaggiatori e pellegrini da Venezia tra Quatro- e Seicento, edited by Sante Graciotti (Rome: Bardi Editore, 2009).

${ }^{70}$ For example Danuta Quirini-Popławska, "Pobyt w Wenecji pielgrzymów udających się do Ziemi Świętej w XIV i XV wieku," Peregrinus Cracoviensis 1998, issue 6: 27-45 [reprinted in:] idem, Italia Mia..., 163-180; idem, Wenecja jako etap podróży do Ziemi Świętej (XIII-XV w.), in Peregrinationes. Pielgrzymki w kulturze dawnej Europy, edited by Halina Manikowska, Hanna Zaremska (Warsaw: Instytut Historii Polskiej Akademii Nauk, 1995), 126-143.

${ }^{71}$ Biliński, Viaggiatori..., 352-353; idem, Venezia nelle peregrinazioni polacche del '500..., 241-249; Ulewicz, Iter Romano-Italicum Polonorum..., 191; Franczak, Hierosolymitanorum processio..., 237-245.
} 
w niedzielę, rozpoczęliśmy podróż z Wenecji (...)"72 [On St. Procopius, which occurred on Sunday, we set off from Venice]. The traveller did not mention his return journey. Jan Goryński's account of his 1560 pilgrimage did not include any information on his visit in Venice on route to the Holy Land. His description began with his arrival in Jaffa. The fact that he departed from Venice was indicated indirectly by a piece of information about the origin of the ship: "Po wieczerzy patron okrętu naszego (...), mniemając też, aby żołdaci beli, którzy by się dowiedzieć chcieli co by był za okręt (...), posłał tłumacza $w$ barce małej, opowiadając im, iż jest okręt wenecki, który przyszedł z pielgrzymy (...)"73 [After supper, the patron of our ship (...), possibly to let soldiers who were there know what ship it was (...), sent an interpreter in a small barge, who told them it was a Venetian ship which arrived with pilgrims (...)]. The description of the return journey also omitted any reference to his visit in the city of doges. The pilgrims did, however, visit Cyprus, which still belonged to the Republic of Venice, they made land in Famagusta, where they admired structures included in the obligatory programme of the pilgrimage trail (St. Catherine's Church), and they visited salty lagoons and Limassol. The account focussed mainly on the selection of the appropriate ship for the remainder of the voyage, and finalising administrative and living matters. ${ }^{74}$

The topic of Prince Mikołaj Krzysztof Radziwiłł's visit to Venice on his way to the Holy Land was discussed by Bronisław Biliński, Leszek Zinkow, and Grzegorz Franczak. ${ }^{75}$ Radziwiłł treated Venice as an administrative centre convenient for finalising matters associated with his further journey to the Holy Land: applying for and receiving documents, acquiring a loan, and selecting a ship (a galley). He first visited Venice and stayed in its vicinity in 1580-1581. He reached the city in late April or early May and he remained there until 24 April of the following year. At that time, he explored the city visiting, e.g. St. Mark's Basilica, the vault, and he met Nicolò da Ponte, Doge of Venice. He eventually abandoned his original intention to set off for the Holy Land as he received news of a plague raging at the destination. ${ }^{76}$ Therefore, his next stay in Venice no longer had the aura of freshness and first impression. Radziwiłł knew the people there and the relations

72 “Dziennik podróży Jana Tarnowskiego do Ziemi Świętej z 1518 roku," trans. Robert Sawa, introduction and edited by Dariusz Chemperek, Odrodzenie i Reformacja w Polsce, issue 49 (2005): 187.

73 "Peregrynacyja do Ziemi Świętej Jana Goryńskiego," in Dwie peregrynacje z XVI wieku (Warsaw: Władysław T. Baranowski, 1914), Prace Komisji do badań nad historią literatury i oświaty, vol. 1, 263-264.

${ }^{74}$ Ibid., 281-289.

${ }^{75}$ Leszek Zinkow, “Wenecja na trasie peregrynacji Mikołaja Krzysztofa Radziwiłła «Sierotki» do Egiptu i Ziemi Świętej," in Terra Culturae. Obszary, transfery, recepcje kultury. Studia oraz szkice o kulturze i historii, edited by Łukasz Burkiewicz (Krakow: Wydawnictwo Naukowe Akademii Ignatianum, 2018), 143-156; Franczak, Hierosolymitanorum processio..., 242-245.

${ }^{76}$ See Tomasz Kempa, Mikołaj Krzysztof Radziwiłt Sierotka (1549-1616). Wojewoda wileński (Warsaw: Wydawnictwo Naukowe Semper, 2000), 114-115; vide also Szczepan Kalinowski, “Pielgrzymki Radziwiłłów w XVI i XVII wieku," Peregrinus Cracoviensis, issue 15 (2004): 65-74; G. Franczak, Hierosolymitanorum processio..., 245; L. Zinkow, Wenecja na trasie peregrynacji Mikotaja Krzysztofa Radziwitła..., 149. 
between them; he was able to focus on preparing the planned journey. In the account translated from Latin into Polish by Andrzej Wargocki (originally edited as the prince's journal and translated into Latin by Tomasz Treter) published in the form of four letters in 1607, which existed in circulation in that form (in parallel to the Latin version) ${ }^{77}$ until the mid-20th century, the arrival of the pilgrim in Venice was the first event which received a specific date. The Lithuanian magnate arrived in the city of doges on 8 December "(...) w samo święto Poczęcia Najświętszej Panny"78 [right on the holiday of the Conception of Virgin Mary]. Owing to his earlier connections and royal letters of recommendation, Radziwiłł had no problem acquiring a letter of recommendation from the previously acquainted doge de Ponte for Venetian captains who fared the Mediterranean and whose native ports were located in seaward parts of the Republic of Venice. He also visited Joannes de Candia, at that time the prosecutor of the Holy Land residing at the Francis della Vigna monastery, ${ }^{79}$ and guardian Jerome de Bressa, who was twice the superior of the Franciscan monastery in Jerusalem (he lived there 12 years in total), to receive directions from them on how to organise his travels. Radziwiłł was keen to set off after 6 January as he intended to reach the Holy Land by Easter. Encouraged by his friends, he chose an already thirteen-year-old galley which belonged to the Tornelli merchant family. It was captained by Augustine de Giacomo. The choice was dictated by the vessel's considerable speed and its "fortuitous" nature. The magnate thus described the size of the ship: "nie był ten wprawdzie wielki, bo tylko sześćset beczek brał"80 [it was not necessarily large as it could only take six hundred barrels]. Thus, Radziwiłł revealed the reason for selecting the ship and approximated his decision-making process. Clearly, what counted was fortuitousness in the sea, speed, and an experienced crew. He decided based on advice from trustworthy locals. The choice proved correct considering the fate of the vessel Ruggina (presumably a regularly faring ship carrying pilgrims to the Holy Land), which sett off later. It was destroyed in a storm near Istria, and its passengers returned to Venice. ${ }^{81}$ Two other ships aboard which Radziwiłł might have travelled through Egypt sank - one near Ragusa, the other near Kerkyra. He was discouraged from using those by his friends who argued that the ships had inexperienced captains. Prior to his departure, the pilgrim had to receive a permit for his journey from the pope. Radziwiłł only requested a renewal of his previously issued permit. The letters were supposed to authenticate the prince in the eyes of Palestine's Christians. The necessity of holding an authenticating letter was supposed

${ }_{77}$ Vide also Franczak, Hierosolymitanorum processio..., 242.

${ }^{78}$ Mikołaj K. Radziwiłł, Peregrynacyja abo Pielgrzymowanie do Ziemie Świętej Jaśnie Oświeconego Pana J[ego] M[ości] P[ana] Mikołaja Chrysztofa Radziwiłła, ksiażęcia na Ołyce i Nieświeżu, hrabie na Szydłowcu i Mir, wojewody wileńskiego, szawelskiego etc. starosty. Przez Jego M[ość] Ks[iędza] Tomasza Tretera, kustosza warmieńskiego, jezykiem tacińskim napisana i wydana..., trans. Andrzej Wargocki (Krakow: Szymon Kempinius, 1611), 11.

${ }^{79}$ See Franczak, Hierosolymitanorum processio..., 245.

${ }^{80}$ Radziwiłł, Peregrynacyja abo Pielgrzymowanie do Ziemie Świętej..., 12; Zinkow, Wenecja na trasie peregrynacji Mikołaja Krzysztofa Radziwiłła..., 150.

${ }^{81}$ See Zinkow, Wenecja na trasie peregrynacji Mikołaja Krzysztofa Radziwitła..., 151. 
to eliminate tourists and pilgrims of other faiths from pilgrim trails, though it is common knowledge that protestant churches disputed the merit of engaging in pilgrimages. Christians feared, according to Radziwiłł, that they would behave inappropriately, which could result in persecutions of Palestinian Christians and them being captured into slavery by Turks. Usually, monks had to pay ransom for such people.

Radziwiłł spent his stay in Venice developing his various contacts, visiting figures, and exploring the location. When describing a journey through Egypt, he mentioned a very large and expensive diamond which he viewed "at a merchant" in the city of doges already in 1580. The precious stone, worth 18,000 szkuds, became the property of rich black merchant, who supposedly gifted it to the sultan as an attachment to a request to punish Asan Basha who ruled Egypt with an iron fist. ${ }^{82}$

The departure was delayed so much that Radziwiłł spent the period of Lent in Venice. The sublimity of the event was stressed by the pathos of the statement. Additionally, Radziwiłł indicated the two-stage nature of the process:

\begin{abstract}
Aż w sobotę tedy, przed niedzielą przewodnią, roku Pańskiego 1583 dnia 16 Aprila, około 22 godziny, w bacik wsiadszy w Wenecyjej, do klasztora S[anctae] Mariae della Gratia zakonu ś[więtego] Hieronima na wyspie przypłynęliśmy (...), a stamtąd w porcie Malamocy, po zachodzie słońca do okrętu wszedszy, o godzinie trzeciej w noc, podnieśliśmy kotwice na świtaniu dnia tego (był 17 Aprila) odbiwszy się, gdy przez dzień i noc, zaś dzień drugi lekki wiaterek powiewał, odnogę tergestyńską minęliśmy.

[On Saturday, then, before the leading Sunday, in the year 1583 of our Lord on the 16th of Aprilis, around 10 in the evening, having boarded a boat in Venice, we arrived at the monastery of Saint Mariae della Gratia of the order of Saint Jeronimo on the island (...), and from there in Malamoca, having boarded the ship after midnight, at three at night, we raised the anchor at dawn of that day (it was 17th of Aprilis) having set off, when through day and night, and on the second day a light breeze blew, we passed the Tergeste's arm]. ${ }^{83}$
\end{abstract}

When describing his stay in Venice and the related endeavours, Radziwiłł did not mention the procedures of granting a loan or a warranty, services which he was supposed to utilise during the voyage. Those details, naturally occurring in the accounts by pilgrims and Venetians, appeared when after pilgrims were mugged on Italian land, the magnate tried to avoid prison for unpaid dues, so he searched for a creditor who having considered him credible, would allow him to take a loan ("szukaliśmy kupca jakiego znajomego, lecz nie znalazszy, gdy naszej drogi przewodnicy, prędkiej odprawy barzo się upominali, gospodyni też, bacząc na nas prawie oszarpane odzienie, a pieniędzy nie widząc, groziła urzędem" ${ }^{\prime \prime 4}$ [we sought

\footnotetext{
${ }^{82}$ Radziwiłł, Peregrynacyja abo Pielgrzymowanie do Ziemie Świętej..., 258.

${ }^{83}$ Ibid., 17; Zinkow, Wenecja na trasie peregrynacji Mikołaja Krzysztofa Radziwiłła...., 151152; Franczak, Hierosolymitanorum processio..., 245.

${ }^{84}$ Radziwiłł, Peregrynacyja abo Pielgrzymowanie do Ziemie Świętej..., 347.
} 
some familiar merchant, but having found none and since our guides were demanding payment, as did our hostess, considering our almost tattered garments and not seeing any money, she threatened us with the authorities]. Since Radziwiłł could not find any familiar merchant in Ancona, he went to the governor. The letters which he presented to the latter were supposed to give him credibility. He needed a warranty which would enable him to take a loan: "(...) prosiłem (...), żeby kupcowi któremu za mnie ręczył, za dwieście szkutów, tylko póki bym do Wenecyjej nie dojechał"85 [I asked (...) him to warrant me before a merchant, for twenty szkuds, until I would reach Venice]. His requests failed, in fact, the governor lost his position soon afterwards, and the magnate found a representative of Quintillus, a Venetian merchant. He pawned his valuables with him, which he was able to hide from the bandits. That was not, unfortunately, enough to continue his journey to Venice, where Radziwiłł had appropriate contacts. He intended to send Jerzy Kos, his servant, to the city yet the travel to and fro would take a week. A return to negotiations with the merchant offered a glimpse into the entire set of documents and letters of recommendation which Radziwiłł was using during his stay on the Mediterranean, both in the Holy Land and in Egypt. The magnate gained the merchant's trust only upon presenting to the potential creditor documents which he received from Venetian merchants, whom the merchant knew not only personally but also was familiar with their handwritings and seals. The sums of warranties which Radziwiłł had were not insignificant:

(...) nie do końca nam dowierzał, zaczym ukazałem mu literas Passus Ojca Świętego, króla polskiego i książęcia weneckiego. (...) Ukazowałem też mu do tego listy od przedniejszych kupców weneckich, które on dobrze znał, tak samych, jako i ręki ich i pieczęci, a te listy były pisane do Syryjej, Egiptu, Kairu, żeby mi tam ich faktorowie dodawali pieniędzy, których suma do kilkuset tysięcy cekinów przychodziła; dla czego już barziej ufał, gdy baczył, jako się i listy między sobą, i z moim imieniem, i z powieścią zgadzały (...)

[he had not believed us before I showed him literas Passus by the Holy Father, the king of Poland, and the Venetian prince. (...) I also showed him letters from major Venetian merchants, and he was familiar both with the people and their hands and seals, and those letters had been written to Syria, Egypt, Cairo, so that there their factors would add me money, the sum of which reached several hundred thousand sequins; that he trusted more when he saw how the letters matched each other, and my name, and my story $]^{86}$

That once again confirmed Radziwiłł's excellent knowledge and contacts with Venetian merchants. One could even argue that the success of the entire journey depended on his extensive contacts with Venetians.

${ }^{85}$ Ibid., 348.

${ }^{86}$ Ibid., 350. 
Radziwiłł documented his participation in Venetian celebrations of St. Mark, the city's patron: "Nazajutrz (było św. Marka) szliśmy do kościoła i byłem na procesyjej, którą po wszytkim weneckim państwie z wielką ceremoniją obchodzą" ${ }^{\prime \prime 7}$ [The following day (it was St. Mark's day) we went to church and I joined a procession in which is known throughout the Venetian state for its ceremonious character].

He remained in almost constant contact with Venetians during his journey. In Peregrynacyja abo pielgrzymowanie, Radziwiłł recorded the names of Venetians who fulfilled the functions of consuls, praetors, and more (Marcus Antonius Venereus, Venetian praetor) ${ }^{88}$ Marcus Securius - tax collector, ${ }^{89}$ Nicolaus de Ponte - doge ${ }^{90}$ Fr. Joannes de Candia - prosecutor of the Holy Land, ${ }^{91}$ Vincentius Morosinus - praetor, ${ }^{92}$ Francis Testarosa, Venetian agent in Tripolis, ${ }^{93}$ Lauretnius Pacificus - companion to the Holy Land, ${ }^{94}$ Thomas Candiota, deputy consul in Damietta, ${ }^{95}$ Paweł Marian - a Venetian, French consul in Cairo, ${ }^{96}$ Francisco Sasso, emissary of Pope Gregory XIII in Alexandria, ${ }^{97}$ Jerzy Emo - a Venetian, a consul in Egypt ${ }^{98}$ Jeronim Witalis - a merchant. ${ }^{99}$

Venetians were authoritative figures for the magnate; he heeded their opinions regarding the choice of ship, captain, crew, and regarding trade affairs. For example, he confirmed information about the size of fruit exports from Zakynthos relying on the opinion of a local tax collector and merchants: “(...) co i Marcus Securius Wenet, natenczas tam mytnik, i inszy kupcy za rzecz pewną twierdzili" ${ }^{\prime 100}$ [what was indicated by Marcus Securius Wenet, a tax collector there at that time, and other merchants as certainty]. Radziwiłł also recorded Venetians' maritime habits. Due to the Turkish threat, Venetian galleys were not allowed to fare alone. A voyage had to be conducted in the company of at least another vessel. ${ }^{101}$

The magnate visited and described a fortress located on one of Venetian islands. It was a proof of basing the strategy of operation on the Republic of Venice, which had many dispersed territories in the form of strips of land located on the continent and numerous islands and peninsulas, on fortified structures, which with their architectures shaped the landscapes of their related lands, being both footholds of Venetian culture and trade: "Forteca ta miała pięć baszt dziwnie obronnych, działy

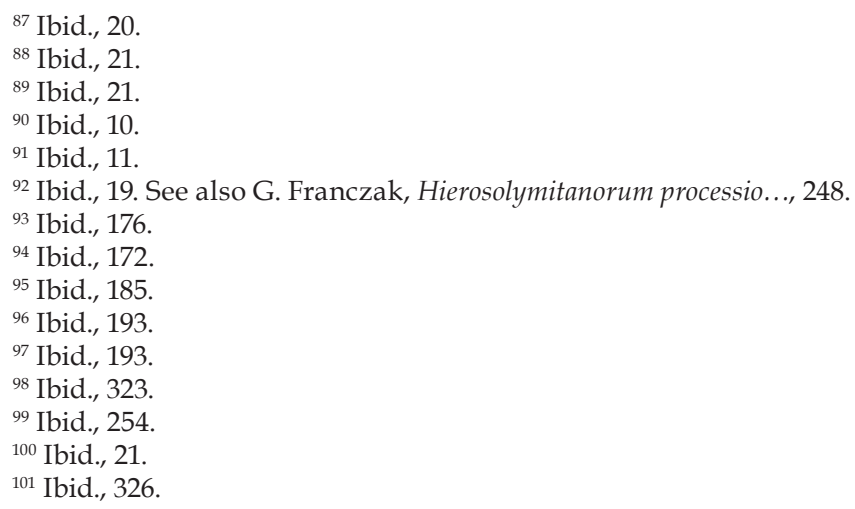


i żołnierzem przednie obwarowana. Port ma barzo szeroki, który stawić do dwu tysiącu naw, a drugie mające $\mathrm{z}$ dział bić, kiedy by potrzeba ukazała może $\mathrm{e}^{\prime 102}$ [The fortress had five towers strangely fortified, guarded first with cannons and soldiers. It had a very broad port, which could fend off up to two thousand ships, and shooting cannons if need be]. The locations were staffed with strong military crews: "Bo iż tam forteca wielka, tedy Wenetowie niemało ludu chowają"103 [Since the fortress is great, Venetians keep there many strong]. The magnate decided not to describe the Crete-located fortress in Candia (Turks captured it as late as in 1669). He only stated: “O położeniu miasta Kandyjej i o obronie jego, która jest wielka, dział mając dostatek przednie znacznych, iż drudzy pisali, ja zaniecham"104 [About the location of the city of Candia and its defences, which are huge, having many major cannons, I shall refrain from writing as others did write that].

Radziwiłł recorded Venetians' military activities at sea and on land; he noticed their considerable activity; he was able to record the high dynamism of their actions, and, thanks to an outside point of view, appreciate the role of Venetian Arsenal as the leading arms factory. He thus presented his observations on Crete:

Siódmego dnia listopada przypłynęło galer weneckich dwanaście z Korcyry, siedm gwardyi, która strzeże około Krety (odwoziły kawalery z Malty, co je byli poimali Wenetowie), a pięć nowych, które oni zowią arcyle i stoją w Arsynale albo przy cekauzie, że czasu wojny, abo jakiej potrzeby je wyprawują. Bo galer nigdzie nie robią, jeno w Wenecyjej, a stamtąd je potym rozsyłają, dokąd ukazuje potrzeba [On the seventh day of November, twelve Venetian galleys arrived from Kerkyra, seven large detachments which defended around Crete (they were escorting troops from Malta whom Venetians captured there), and five new ones, which stood in the Arsenal or by the workshop ready for war or another need. Galleys are done nowhere else but in Venice, and then they send them out from there where they are needed. ${ }^{105}$

A view on the Venetian Arsenal and its expanse from the outside, from distant territories and provinces, and from the perspective of military activity at sea of the ships normally stationed in Venice enabled him to assess in practice the significance of the military potential of the Republic and the special role of that part of the city for maintaining its position in the international arena, particularly in political activities conducted in reference to its potential enemies. The Arsenal was a native port and an exceptional factory - a military centre which enabled the Republic to be the regional political leader, or at least a major player.

\footnotetext{
102 Ibid., 313.

${ }^{103}$ Ibid., 304.

${ }^{104}$ Ibid., 302.

${ }^{105}$ Ibid., 302-303.
} 
The magnate was aware of the existing political situation, and how the Venetian state functioned. He described the processing of complaints against soldier gambolling not only in theory but also in practice: "Kiedyśmy byli w Zarze, skargę czyniono na sto dwudziestu człeka żołnierskiego, które Senat Wenecki tejże naszej nawie od wyspu Krety posyłał, gdzie praetor rozkazał tudzież, aby szkody każdemu płacili"106 [When we were in Zara, a complaint was filed against one hundred and twenty soldier strong, whom the Venetian Senate sent to our ship in Crete, where praetor ordered payment of damages to all]. Radziwiłł also recorded a successful action by "special forces" conducted in Alexandria, the aim of which was to remove the relics of St. Mark: “(...) gdzie długo ciało święte po męczenniku leżało, aż go Weneci przemyślnie a potajemnie (...) wziąwszy do Wenecyjej zawieźli, z uczciwością wielką, o czym mówi historyja"107 [where the holy body of the martyr lied, until Venetians ingeniously yet secretly (...) brought to Venice, with great honesty, of which history talks]. This passage indicates how important it was for Venetians to establish a kind of origin myth associated with the cult of St. Mark and the basilica devoted to him.

Radziwiłł described Venetians' ability to govern, manage space and property acquired at any location: “(...) na noc potym do Kawuzy, przez dolinę obfitą i wesołą, kędy szlachcic wenecki zamnożył cyprysowy gaj i pięknym rzędem drzewa rozsadzone stoją"108 [for the night Kawuza, through a bountiful and merry valley, where a Venetian noble spread a cypress forest and trees stand in beautiful lines].

Venetians settled not only in territories which belonged to the Republic, but also for other reasons, both for trade and even reasons of morality. They often left a permanent mark. In Tripoli, the magnate encountered the following situation:

Jest tam także wedla morza wieża z kamienia kwadratowego, nader wysoka, z herbami jednego szlachcica weneckiego, który z jedną murzynką grzech cielesny popełnił (co tam w chrześcijanach gardłem karzą) trudność wielką miał i taką wieżę groszem swoim zmurowaną, ledwie się okupił

[There is also there, by the sea, a tower of square stone, very high, with the emblems of a Venetian noble, who committed a carnal sin with a Negro (which is punishable by death among Christians there), he had much trouble and he erected such a tower with his money the moment he came into money]. ${ }^{109}$

He also visited the ports which belonged to the Republic of Venice many times, e.g. Kythira (Cerigo Cytherea), one of the Ionian Islands. ${ }^{110}$ Many of those offered opportunities to admire the relics of the ancient world and an

\footnotetext{
106 Ibid., 20.

${ }^{107}$ Ibid., 262.

${ }^{108}$ Ibid., 301.

${ }^{109}$ Ibid., 168-169.

${ }^{110}$ Ibid., 318.
} 
excuse to spin cultural reflections. ${ }^{111}$ The Republic's ports on the Adriatic also offered an opportunity to come into contact with Slavs. ${ }^{112}$

The story of his visit in Tripoli offered an introduction into the world of successful trade relations. Harmonious cooperation brought mutual benefits: "Słudzy jego wielką mieli przyjaźń z Franciszkiem Testarosą, agentem w tych miejscach Rzeczypo[spolitej] Weneckiej, która przyjaźń była między nimi, gwoli cłu od towarów, gdyż od nich tenże agent płacił"113 [His servants had great affinity with Francis Testarosa, an agent in those locations of the Republic of Venice, which affinity was between them, in view of goods tax, as the agent paid that]. Radziwiłł also described the loading of ships, and the port life in Tripoli: “(...) nadto okręty weneckie, i które w chrześcijańskie strony jachały, naładowane jeszcze nie były, a o mnie się też barzo pilno, kto bym był pytano (...)"114 [also Venetian ships, and those which were to set off to Christian parts, were not yet loaded, and they were very careful about me, to whom I talked].

Venetians were present almost throughout the area of the Mediterranean. No wonder, then, that Radziwiłł met with them to acquire loans or gain information. They also constituted a reliable source of information about people and the oriental world. For example, the magnate echoed the opinion of a Venetian merchant regarding people bought out from Turkish captivity: "Kupiec niejaki wenecki, który w Kairze długi czas mieszkał, twierdził za rzecz pewną, że z tych okupionych ledwie co bywa dobrego"115 [One Venetian merchant, who lived in Cairo for a long time, claimed that those bought out are rarely any good].

Having completed his journey through the Holy Land, Radziwiłł sent some of his things to Venice, which he considered a safe port, a kind of a starting point where he could store his belongings without fear while engaging in further travels: "Potym gotowałem się w drogę i rzeczy do okrętu weneckiego, w którymeśmy byli przyjechali, wnieść rozkazawszy, zostawiłem przy nich sługę jednego, aby ich w najętej komorze strzegł i do Włoch zawiózł (...)"116 [Afterwards I was getting ready for departure and having ordered to load my belongings on the Venetian ship aboard which we had arrived, I left one servant with them, so he guarded the rented chamber and escorted to Italy]. With the belongings, the servant was escorting Ms. Siekierzycka, a Pole, whom the prince evacuated from Palestine. ${ }^{117}$

\footnotetext{
111 See Hieronim Kaczmarek, "Mikołaja Krzysztofa Radziwiłła Sierotki «podróż po starożytnym świecie»," Baltica Posnaniensia, issue 4 (1989): 343-351.

112 See Józef Magnuszewski, “Dwa południowosłowiańskie epizody podróży do Ziemi Świętej księcia Mikołaja Krzysztofa Radziwiłła zwanego Sierotką,” in Polska - Jugosławia. Związki i paralele literackie, edited by Halina Janaszek-Ivaničkova and Edward Madany (Wrocław, 1987), 29-37; idem, "Dwa renesansowe itineraria: Radziwiłła Sierotki i Václava Vratislava. Miscellanea," in Stowiańszczyzna zachodnia i południowa. Studia i szkice literackie (Warsaw: PWN, 1995), 63-77.

${ }^{113}$ Radziwiłł, Peregrynacyja abo Pielgrzymowanie do Ziemie Świętej..., 172.

114 Ibid., 176

115 Ibid., 273.

116 Ibid., 176.

117 Ibid., 169.
} 
The magnate was often received in Venetian ports by the Republic's officials as an official guest. He was usually received lavishly and with honours, ensuring proper allowances. That was possible thanks to appropriate Venetian letters: "Miano mi było tu dać parę galer, które by mię do Włoch odwiozły, jakoż miałem na to list od Rzeczypospolitej Weneckiej do sprawc tego tu miejsca (...)"118 [I was supposed to be given several galleys here, which would take me back to Italy, as I had a letter from the Republic of Venice for the administrator of the location]. In Alexandria, Radziwiłł was accompanied during the paying of tax by a Jew who worked for a Venetian consul. ${ }^{119}$

Several times throughout Egypt, Radziwiłł benefited from the rights which applied to Venetian merchants. That was possible when he remained in their company. He thus visited the port in Alexandria. ${ }^{120}$

The network of transport facilities developed by Venetians proved useful. Radziwiłł used, e.g. Venetian mail service, which operated within the area of the Mediterranean ${ }^{121}$; he noted the traffic of ships, including the one aboard which he left the capital: "Zastaliśmy w Trypolu onę wenecką nawę nasze, którąśmy byli w Cyprze odprawili, z wielą tu była inszych świeżo z Wenecyjej przypłynęła, kędy mi też z Litwy listy pospołu przysłano"122 [We found in Tripoli that Venetian ship of ours, which we sent off on Cyprus; it arrived fully loaded fresh from Venice, and it also brought letters for me from Lithuania].

The magnate also used a network of inns, which Venetian merchants had in cities not included in the Republic. For example in Tripoli, at the same time explaining the name: "Na brzeg wyszedszy, szliśmy pół mile do miasta, i stąpiliśmy do fonteka, karwasery abo weneckiego mieszkania"123 [Having stepped on land, we walked half a mile into the city, and we entered a fontek, a karwasera or a Venetian apartment]. Radziwiłł also used a Venetian inn in Alexandria, ${ }^{124}$ and he recorded the presence of another two which belonged to other European states. ${ }^{125}$ In Tripoli, he was not unknown to Venetian merchants who were staying there: "(...) udaliśmy się do karwasery weneckiej, gdzie nas znajomi przywitawszy wdzięcznie, do siebie przyjęli"126 [we went to a Venetian karwasera, where our acquaintances having welcomed us cordially invited us to join them]. During his stay in Cairo, Radziwiłł used the house of Paweł Marianus, a Venetian consul, which was located opposite the consulate. ${ }^{127}$ The consul accompanied the magnate during the latter's explorations of Egypt - he travelled on a barge on "a major canal" with him, and he visited a village called Natarea. ${ }^{128}$ The

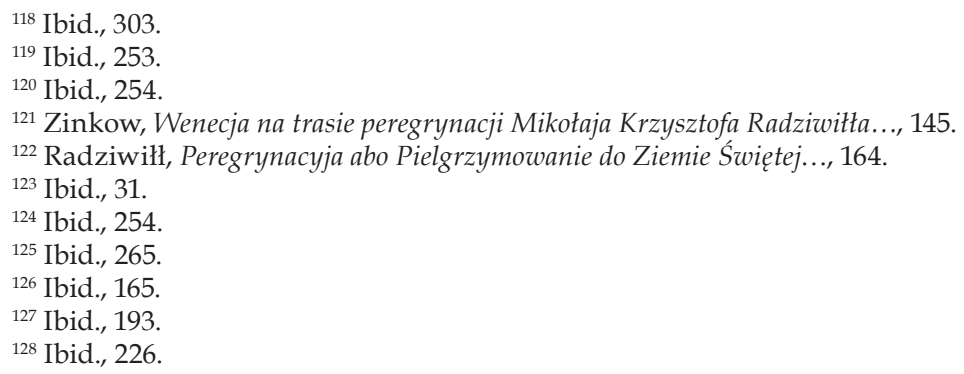


consul was also helpful in confirming the amount of the fee demanded by Egyptians for a deceased barber surgeon of three sequins. ${ }^{129}$ Jerzy Emo, a Venetian, accompanied Radziwiłł and his entourage during a trip to the pyramids and they descended to the underground section. ${ }^{130}$ The consul also sent back to Lithuania, at the request of the magnate, two young men he bought out from Turkish captivity. ${ }^{131}$

Radziwiłł also learnt in more detail about the functioning of Venetian administration in foreign lands. He described the story of a Venetian by the name of Antonius, who had to be bailed out from prison by the Venetian consul in Cairo after the former was handed over to the city's governor by Turks "(...) aż go był konsul wenecki, gdyż Antonius był Wenet, wyręczył"132 [until the Venetian consul, as Antonius was a Venetian, did that instead]. The importance of the Republic of Venice in the area of the Mediterranean was proven by the wartime incidents which were witnessed by Radziwiłł, being their would-be victim. ${ }^{133} \mathrm{He}$ described the course of the rivalry at sea between Philippous Pasqualinus, a Venetian captain, a leader of seven galleys, and a Turkish fleet led by Okialy, from whom Venetians seized two Maltan galleys with crews and refused to return them. ${ }^{134}$

When departing from Alexandria, Radziwiłł passed a ship heading for Venice. On his return journey he wished to visit the territory of the Republic of Venice: "Czwarta nasza Salicyja francuska niewielka, którąm najął, i miała mię wysadzić w Krecie, iż stąd chciałem do Europy galerami jechać przez Państwo Weneckie, kędy mogłem sobie nieco wytchnąc, znajomych siłu mając, a do tego, jeśliby morze dla zimy bliskiej jechać nie dopuszczało"135 [Our fourth small French Salice, which I had rented and which was supposed to let me off on Crete as from there I wished to travel on galleys to Europe through the Venetian State, where I could rest for a while, having many acquaintances if the sea would allow further travel for the soon coming winter].

Ending his journey, the magnate decided to head to Venice, his second home, for Easter of $1584 .{ }^{136} \mathrm{He}$ returned from the pilgrimage via, of course, a maritime route. Yet Radziwiłł reached the city of doges only on Tuesday after Easter. The fact of reaching a well-known place triggered memories in him of the starting point of his journey: "(...) po obiedzie płynąłem do Wenecyjej, a minąwszy Port Mamalocho, w którymem był wsiadał w nawę do Jeruzalem, przystąpiłem do kościoła S[ancta] Mariae della gratia (...)"137 [after dinner I went to Venice, and having passed Port Mamalocho, where I had boarded a ship to Jerusalem, I entered the church Sancta Mariae della gratia].

${ }^{129}$ Ibid., 234.
${ }^{130}$ Ibid., 245.
${ }^{131}$ Ibid., 271.
${ }^{132}$ Ibid., 287.
${ }^{133}$ Ibid., 288.
${ }^{134}$ Ibid., 288.
${ }^{135}$ Ibid., 280.
${ }^{136}$ Ibid., 351.
${ }^{137}$ Ibid., 352. 
There, too, Radziwiłł encountered the standard procedure of routine sanitary inspection which was used also in other Venetian ports. That was because Venetians were afraid of someone brining in a plague: "Potym przyjechaliśmy pod Wenecyją, kędy Urząd zwyczajny oglądał fedę, żeśmy zdrowego powietrza (...)"138 [Then we went to Venice, where the regular office conducted an inspection, to make sure we were of healthy air]. A positive result enabled the visitor to proceed. A similar inspection was conducted in Zara. ${ }^{139}$ He travelled to the city via gondola. Venetians guarded access to their capital not only for military reasons, but also due to sanitary considerations. At almost every step, the excellent organisation of the Republic of Venice, based on strict administrative discipline, became apparent. A wealthy person with appropriate contacts with Venetians was able to avoid risks by utilising the Republic's state system and trade organisation, and the network of ports and inns.

Venice also offered Radziwiłł haven to rest after his travels: "Potym tą drogą w Wenecyjej mieszkał, iżem i barzo słabym zdrowiem przyjachał, ustawiczniem się leczył (...)"140 [Then after the journey I stayed in Venice, as I arrived in very poor health, I was recuperating constantly]. His therapy did not prevent him from conducting token visits. He had to settle the missions with which he was entrusted, and the letters he received. He was not able to complete all his objectives. He returned two letters to a rector from Zakunthos, which he was not able to deliver ${ }^{141}$ Radziwiłł was carrying a letter to Stefan Batory from the Venetian doge. He set off for his return trip, as he himself indicated, on 3 May 1584. He then left Venice heading for Trento and Vienna.

Radziwiłł's text offered an image of Venice as a strong centre of administration, trade and military potential presented through its economic operations radiating throughout the area of the Mediterranean. Venetian merchants, Venetian merchant houses, agents and consuls created a network of contacts enabling movement also for people with appropriate associations - rooted in Venice through financial, trade, representational or social relations.

${ }^{138}$ Ibid., 352.

139 "Po obiedzie, nająwszy sobie barkę do Zary miasta weneckiego w Dalmacyjej leżącego, przednie obronnego, po godzinie 21 puściłem się i dojechałem, kędy u portu wenecki praetor Vincentius Morosinus przechadzał się i chciał wiedzieć, jeśliśmy z dobrego powietrza. Pisarz nasz z barki wyszedszy, ukazał mu paszport, który gdy przeczytał, kazał nam z batu na ląd wysieść (...)" (19) [After dinner, having rented a barge to Zara, a Venetian city in Dalmatia, superbly fortified, after 9 in the evening I set off and arrived, when at a Venetian port praetor Vincentius Morosinus was strolling and wanted to know whether we were of fair air. Our scribe, having emerged from the barge, presented a passport after reading which the preator ordered us to step onto land]. A similar procedure applied to the entry at the port in Candia: “A gdyśmy do portu dla wiatrów nie mogli wjachać, wysiedliśmy na brzeg, kędy nieco, aż by z naszego paszportu obaczono, że z zdrowego miejsca jedziemy, musieliśmy czekać" [And we could not enter the port due to wind, we stepped ashore, where they checked our passport to see that we were of fair air, we had to wait] (Radziwiłł, Peregrynacyja abo Pielgrzymowanie do Ziemie Świętej..., 22). Cf. Franczak, Hierosolymitanorum processio..., 248.

${ }^{140}$ Ibid., 353.

${ }^{141}$ See Zinkow, Wenecja na trasie peregrynacji Mikołaja Krzysztofa Radziwiłła..., 152. 
Only a view of Venice from the outside, as a result of versification of "entries," which the city guide established by indicating major structures, enabled one to appreciate their significance not only within the metropolis, but also their major function in the functioning of the entire state. The spiritual Venetian community was cemented within the circle of the religious cult of St. Mark surrounding the basilica; the Venetian Arsenal was an arms factory supplying the entire state, also having a monopoly in the construction of galleys which determined the maritime strength of Venice; the Doge's Palace was a place which symbolised strong republican authority based on efficient administration and discipline; the port and merchant stores symbolised its economic strength, and the many contacts its close cooperation within a network of connections, trust associated with credit ensuring a constant flow of money.

For Radziwiłł, Venice became a window onto the world, an arm which enabled him to safely reach not only the Holy Land, but also Egypt by utilising a network of points Venice operated in the region. The contacts he established and the letters with which he was entrusted enabled him to complete his pilgrimage and explore the region.

Through the translation by Andrzej Wargocki of Peregrynacyja arabska, the description of the 15th-century German pilgrim Breidenbach's arrival in Venice, the Holy Land and Egypt has been considered part of Polish literature since the beginning of the 17th century, i.e. in $1610 .{ }^{142}$ The arrival of a galley with pilgrims and the customs associated with the reception of the returning ones were thus presented by the reporter:

On 8 January we saw the city of Venice. Yet the moment Venetians saw us, they immediately ordered us to slow down and many strong in barges came against us, as they would usually act when their ship or galley returned in good fortune. In from of St. Nicolas's port galleys waited, and we, having given quite a lot of money at the gate, travelled on barges with our belongings to an inn, rejoicing we had reached a decent place. ${ }^{143}$

All the accounts (by travellers visiting Italy and pilgrims heading for the Holy Land) had the unifying quality that the Republic of doges was an intermediate stage of their travels. Depending on their destinations, they either focussed on its relationship with the sea or on the land-bound aspect.

Jan Stanisław Bystron indicated that in the 17th century almost no significant figures completed pilgrimages to the Holy Land. The travellers heading towards that destination did not develop any records of their journeys. The researcher assumed that this was the case due to Radziwiłł's

${ }^{142}$ The work translated by Wargocki was referenced by Biliński (Viaggiatori Polacchi a Venezia..., 356-357).

${ }^{143}$ [Bernhard von Breidenbach], Peregrynacyja arabska albo do grobu ś[więtej] Katarzyny, panny i męczenniczki, którą aniołowie świeci w Arabijej na górze Synaj pogrzebli, zacnych ludzi niektórych rodu niemieckiego, w roku Pańskim 1483. Pielgrzymowanie. Imiona ich sa niżej. Ma rzeczy $i$ z strony nabożeństwa, $i$ spraw potocznych zaprawde dziwne i czytania godne, przekładania ks. Andrzeja Wargockiego, Krakow, in the print shop of Szymon Kempini, year of our Lord 1610, 112. 
authoritative stance and the popularity of his account. Only Melejusz Smytrocki, a Ruthenian, developed an account in Polish of his journey to the Holy Land. In the Apologia, he did, however, focus on theological issues, which was why the description of the journey was scant. ${ }^{144} \mathrm{He}$ arrived at the destination via land thus avoiding Venice altogether. Bystron uncovered a list of pilgrims who in the 17th century reached the Holy Land in a register of visitors held by Franciscans. ${ }^{145}$

The accounts by pilgrims heading for the Holy Land in the final decades of the 16th century were replaced in the 17th century by the increasingly more common journals and diaries of pilgrims who travelled through Europe for educational and tourist purposes. For them, Venice was a major urban centre in their travels. They were interested in the historical sites, history itself, and customs. Those included, e.g. Radziwiłł the Orphan's brother Jerzy Radziwiłł, as well as Maciej Rywocki,, ${ }^{146}$ Jakub Sobieski, Tomasz Zamoyski, ${ }^{147}$ and, finally, prince Władysław Waza. ${ }^{148}$

Jerzy Radziwiłł spent only one day (3 December) in Venice in 1575. Within that time he managed to visit St. Mark's Church, the Doge's Palace, the Arsenal, and take a cruise on the Grand Canal. ${ }^{149}$ His remarks read: "In Mergiera conscendi navem gundulla appellatum, quo genere venetiis per urbem vehuntur et navi per mare 7 mill."150

Maciej Rywocki arrived in Venice from Padua on 29 December 1584. He concluded an initial impression of surprise that it was a city on water, located two miles from shore, and that "w mieście po ulicach okręty chodzą"151 [in the city ships go through the streets]. He admired St. Mark's Square, the marble monuments in St. George and St. Mark's Churches; he boasted of having visited the mint, of having ascended the tower by St. Mark's Church from where he admired to city's panorama; he described the phenomena of low and high tide; he admired the obelisk which fulfilled the role of gallows, one for the commons and one for illicit doges, and he admired the architectural elements made of marble. When describing interpersonal relations, he concluded that the power of doges was only apparent. Rywocki was amazed by the overwhelming order in the sphere of attire. Significantly, that observation existed side by side with a description of structures used for strict enforcement of the law. The traveller remembered the chaos in the sphere of attire which existed in the Commonwealth, a topic often raised by Old Polish moralists (e.g. Rej in Krótka rozprawa, and Kochanowski in Satyr). Rywocki wrote: "A Venetian noble cannot stroll Venice, which is a law, in black

${ }^{144}$ Jan S. Bystroń, Polacy w Ziemi Świętej, Syrii i Egipcie 1147-1914 (Krakow: Księgarnia Geograficzna Orbis, 1930), 46-48; Franczak, Hierosolymitanorum processio..., 243.

${ }^{145}$ Bystroń, Polacy w Ziemi Świętej..., 42-46.

${ }^{146}$ Maciej Rywocki, Księgi peregrynackie (1584-1587), published by Jan Czubek (Krakow: Nakładem Akademii Umiejętności, 1910), 18-23.

${ }^{147}$ See "Wstęp," in Podróż królewicza Władysława Wazy do krajów Europy Zachodniej w latach 1624-1625 w świetle ówczesnych relacji, edited by Adam Przyboś (Krakow, 1977), 8-9.

${ }^{148}$ Podróż królewicza Władysława Wazy..., 376-389.

${ }^{149}$ See “Dziennik podróży do Włoch biskupa Jerzego Radziwiłła w 1575 r.," edited by Henryk Barycz, Kwartalnik Historyczny, issue 49 (1935): 344, 354.

${ }^{150}$ Ibid., 354.

${ }^{151}$ Rywocki, Księgi peregrynackie..., 18. 
cassock all the way to the ground; on that cassock wrapped with a belt of black velvet, a three-finger wide silver-embellished black magierka [a hat], with a single narrow sleeve which he hangs over himself."152

The account also described the procedure of selecting doges, a yearly ceremony on Ascension Day establishing a covenant between the ruler and the sea, and it offered a short description of the Arsenal, a kind of an arms factory.

Stanisław Reszka, while staying in Italy in 1588-1590, fulfilled diplomatic duties. Naturally, he was not interested in historical sites, only official meetings and behind-the-scenes activities, in general: the course of diplomatic issues with which he was entrusted. Reszka stayed in Venice between 20 and 23 April 1588. ${ }^{153}$

Since pilgrims often stopped in Venice for some time before continuing their travels, the remarks related to their stays in the city were noteworthy. From the Commonwealth to Venice there mainly came magnate and szlachta sons completing their European educational journeys.

Samuel Twardowski had a chance to describe Venice one more time when writing an account of the journey of Prince Władysław Waza between 4 and 18 March 1625. Other accounts documenting the journey offered parallel descriptions of the city: by Jan Hagenaw, Stanisław Pac, Albrycht Stanisław Radziwiłł. ${ }^{154}$ What was the prince supposed to admire? According to Twardowski: the wealth of city, the fact that instead of walls, the sea was the city's fortifications, the parliament and the "floating palaces," St. Mark's Basilica and the library, the statue of the lion on the column, the seat of the senate which he visited during an audience:

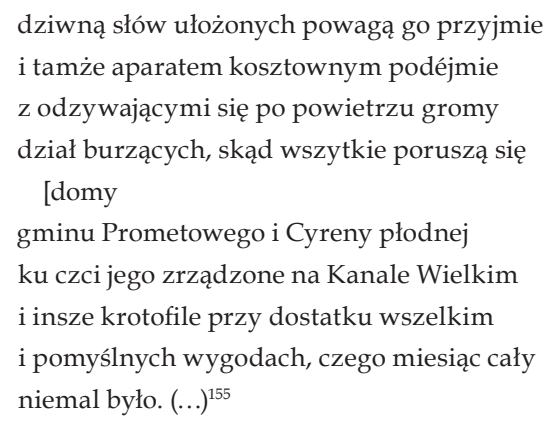

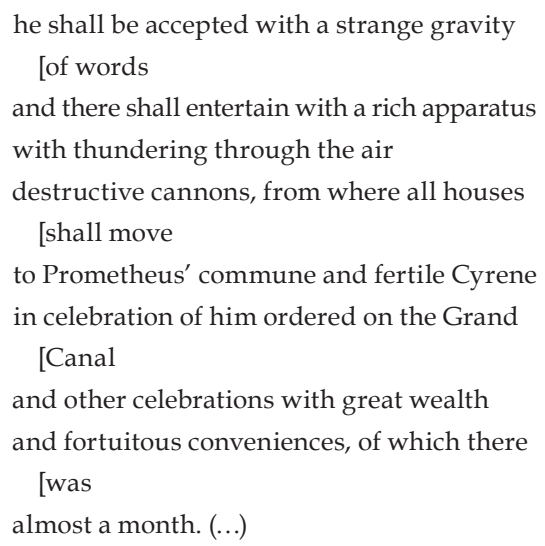

${ }^{152}$ Ibid., 22.

${ }^{153}$ See "Stanislai Resci diarium 1583-1589," edited by Jan Czubek, Archiwum do Dziejów Literatury i Oświaty w Polsce, series I, vol. 15, part 1, Krakow (1915): 201-202. Vide also introduction by Czubek, XIII.

${ }^{154}$ Vide Podróż królewicza Wtadystawa Wazy..., 373-389.

${ }^{155}$ Samuel Twardowski, Władysław IV, król polski i szwedzki, published by Roman Krzywy (Warsaw: Instytut Badań Literackich Wydawnictwo, Pro Cultura Litteraria, 2012), Biblioteka Pisarzy Staropolskich, vol. 40, 195, lines 1381-1390. 
Diarists referenced official meetings with the doge and sons of senators, the magnate's participation in evening theatre performances, concerts, a visit to the Doge's Palace, at the Arsenal and at St. Mark's Square, and the browsing of merchant stalls. They often focussed on the prince's safety, the ability to avoid official receptions, and the fact of reaching an interesting place while incognito. Venice appeared in those accounts as a rich city of merchants and artists ready to hold celebrations in lavish feasts, street shows, and balls.

\section{Conclusion}

In the Old Polish period, Venice was something more than just a city built on water neighbouring the popular academic centre (among Poles) of Padua. It was also an attractive model system, a starting point for pilgrims heading for the Holy Land and Egypt, a major player in the international arena, an adversary of the Ottoman Empire, and a trade partner, in essence "cudowny konglomerat swojskości i obcości" [a wonderful conglomerate of familiarity and foreignness].

Poles admired Venetian buildings, carnivals, street shows, but also the state's political achievements, which they could not apply to their homeland fearing the limiting of state (szlachta's) civil liberties. Therefore, they saw the systemic analogies, the slogan of liberty was used as a common feature. They also appreciated Venetians' openness to the world, their travels, and trade. That dynamism, resourcefulness, and competence could have been that which Poles learnt at the doge's city and which they transferred in practice onto the Polish reality.

Old Polish texts allow one to consider Venice as a kind of the centre of the Mediterranean Christian world governed by pragmatism. Consideration from the side of the Ottoman Porte, Palestine, or Egypt, where Venetian merchants, trade representatives and consuls could be met and a look at armed galleys enable a better understanding of the phenomenon of the city and its system. Its wealth and celebrations, but also deadly struggles of merchants and soldiers at sea, the meeting of work and celebrated rest, religion with the cult of St. Mark - all that charmed visitors from the North pulling them into a whirlwind of life. Venice was a safe stable port to which pilgrims could return crossing the border of European culture, setting off for the oriental world which was dominated by Islam and which was governed by different principles of treating individuals. Cultural osmosis and a creative idea about one's own existence, the mixing of masses of people from different states and religions made Venice in the eyes of visitors from the distant Commonwealth an interesting place, constituting a safe port and a window onto the world.

\section{REFERENCES}

Backvis, Claude. "Jak w XVI wieku Polacy widzieli Włochy i Włochów." In Claude Backvis, Szkice o kulturze staropolskiej. Selected and edited by Andrzej Biernacki, 687-769. Warsaw: Państwowy Instytut Wydawniczy, 1975. 
Barycz, Henryk. Spojrzenia w przeszłość polsko-włoska. Wrocław: Zakład Narodowy Imienia Ossolińskich - Wydawnictwo, 1965.

Biliński, Bronisław. "Venezia nelle peregrinazioni polacche del Cinquecento e lo «Sposalizio del Mare » di Giovanni Siemuszowski (1565)." In Italia, Venezia e Polonia tra umanesimo e rinascimento, a cura di M. Brahmer, 233-290. Wrocław: Zakład Narodowy Imienia Ossolińskich - Wydawnictwo Polskiej Akademii Nauk, 1967.

Biliński, Bronisław. "Viaggiatori polacchi a Venezia nei secoli XVII-XIX (saggio preliminare: esempi ed osservazioni generali)." In Venezia e la Polonia nei secoli dal XVI al XIX, a cura di Luigi Cini, 341-417. VeneziaRoma: Istituto per la Collaborazione Culturale, 1968.

Bogucka, Maria. Bona Sforza. Wrocław: Zakład Narodowy Imienia Ossolińskich Wydawnictwo, 1998.

Brahmer, Mieczysław. Powinowactwa polsko-włoskie. Z dziejów wzajemnych stosunków kulturalnych. Warsaw: PWN, 1980.

[Breidenbach, Bernhard von]. Peregrynacyja arabska albo do grobu ś[więtej] Katarzyny, panny i męczenniczki, która aniołowie świeci w Arabijej na górze Synaj pogrzebli, zacnych ludzi niektórych rodu niemieckiego, w roku Pańskim 1483. Pielgrzymowanie. Imiona ich są niżej. Ma rzeczy i z strony nabożeństwa, i spraw potocznych zaprawde dziwne i czytania godne, przekładania ks. Andrzeja Wargockiego. Krakow, 1610.

Bystroń, Jan Stanisław. Polacy w Ziemi Świętej, Syrii i Egipcie 1147-1914. Krakow: Księgarnia Geograficzna Orbis, 1930.

“Dziennik podróży do Włoch biskupa Jerzego Radziwiłła w 1575 r.” Edited by H. Barycz, Kwartalnik Historyczny, issue 49 (1935): 340-356.

“Dziennik podróży Jana Tarnowskiego do Ziemi Świętej z 1518 roku." Trans. Robert Sawa, introduction and edited by Dariusz Chemperek, Odrodzenie i Reformacja w Polsce, issue 49 (2005): 183-194.

Franczak, Grzegorz. "Hierosolymitanorum processio. I pellegrini polacchi tra Venezia e Dalmazia." In La Dalmazia nelle relazioni di viaggiatori e pellegrini da Venezia tra Quatro- e Seicento. Edited by Sante Graciotti, 235-254. Rome: Bardi Editore, 2009.

Frycz Modrzewski, Andrzej. Ad Serenissimum et Inclytum Regem Poloniae Sigismundum Augustum Lascius sive de poena homicidi. Cracoviae, 1543.

Georgiewicz, Bartłomiej. Rozmowa z Turczynem o wierze krześcijańskiej i o tajności Trójce Świętej, która w Alkoranie stoi napisana. Krakow: Helena Unglerowa, 1548.

Górnicki, Łukasz. "Droga do zupełnej wolności." In Łukasz Górnicki, Pisma. Edited by R. Pollak, vol. 2, 477-529. Warsaw: Państwowy Instytut Wydawniczy, 1961.

Górnicki, Łukasz. "Rozmowa Polaka z Włochem o wolnościach i prawach polskich." In Łukasz Górnicki, Pisma. Edited by R. Pollak, vol. 2, 327474. Warsaw: Państwowy Instytut Wydawniczy, 1961.

Grochowski, Stanisław. Włoskie miasta co przedniejsze, Krakow, 1599. [reprinted in:] Stanisław Grochowski, Rzym nowy szczęśliwszy nad stary, (Krakow, 1610). [reprinted in:] Pielgrzym wtoski albo krótkie Rzymu i miast przedniejszych włoskich opisanie. Teraz nowo z włoskiego na polski język 
przetożone. Przez Franciszka Cesariusa. Przydane są od tegoż drogi i gościńce cudzoziemskie, rachując wszędy dalekość ich na mile własne każdego Państwa, przy tym też wiadomość niemieckiej i włoskiej monety. Krakow: Dziedzice Jakuba Siebeneichera, 1614.

Grześkowiak-Krwawicz, Anna. "Admirabilis ordo. Polacy wobec mitu Wenecji." In Literatura, historia, dziedzictwo. Prace ofiarowane Profesor Teresie Kostkiewiczowej. Edited by Tomasz Chachulski and Anna Grześkowiak-Krwawicz, 67-77. Warsaw: Instytut Badań Literackich, 2006.

Grześkowiak-Krwawicz, Anna. "Rzeczpospolita - pojęcie i idea w dyskursie politycznym Rzeczypospolitej Obojga Narodów. Rekonesans." Odrodzenie i Reformacja w Polsce, issue 65 (2012): 5-35.

Kaczmarek, Hieronim "Mikołaja Krzysztofa Radziwiłła Sierotki «podróż po starożytnym świecie»." Baltica Posnaniensia, issue 4 (1989): 343-351.

Kalinowski, Szepan "Pielgrzymki Radziwiłłów w XVI i XVII wieku." Peregrinus Cracoviensis, issue 15, (2004): 65-74.

Kempa, Tomasz. Mikołaj Krzysztof Radziwitt Sierotka (1549-1616). Wojewoda wileński. Warsaw: Wydawnictwo Naukowe Semper, 2000.

Koranyi, Karol. "La costituzione de Venezia nel pensiero politico della Polonia." In Italia, Venezia e Polonia. Tra umanesimo e rinascimento, a cura di Mieczysław Brahmer, 206-214. Wrocław: Zakład Narodowy Imienia Ossolińskich Wydawnictwo Polskiej Akademii Nauk, 1967.

Kot, Stanisław. Venezia vista dai Polacchi nel corso dei secoli, ed. Francesco Montuoro. Venezia: Dr. Francesco Montuoro - Editore, 1947.

Kuran, Michał. "Anti-Turkish literature in the Polish-Lithuanian Commonwealth, 1575-1733." In Christian-Muslim Relations. A Bibliographical History, Volume 14: Central and Eastern Europe (1700-1800). Edited by David Thomas, John A. Chesworth, 471-493. Leiden-Boston: Brill, 2020.

La Dalmazia nelle relazioni di viaggiatori e pellegrini da Venezia tra Quatro- e Seicento, edited by Sante Graciotti. Rome: Bardi Editore, 2009.

Magnuszewski, Józef. "Dwa południowosłowiańskie epizody podróży do Ziemi Świętej księcia Mikołaja Krzysztofa Radziwiłła zwanego Sierotką." In Polska - Jugostawia. Zwiazki i paralele literackie. Edited by Halina Janaszek-Ivaničkova and Edward Madany, 29-37. Wrocław: Zakład Narodowy Imienia Ossolińskich - Wydawnictwo Polskiej Akademii Nauk, 1987.

Magnuszewski, Józef. “Dwa renesansowe itineraria: Radziwiłła Sierotki i Václava Vratislava. Miscellanea." In Stowiańszczyzna zachodnia i południowa. Studia i szkice literackie, 63-77. Warsaw: PWN, 1995.

Mazurkiewicz, Roman. "Wstęp." In Andrzej Wolan, De liberatate politica sive civili *O wolności Rzeczypospolitej albo ślacheckiej (ttumaczenie Stanisława Dubingowicza). Edited by Maciej Eder and Roman Mazurkiewicz, 9-53. Warsaw: Wydawnictwo Neriton, 2010.

Norwich. John J. Historia Wenecji. Trans. Jakub Bartoszewicz, 2nd edition. Warsaw: Wydawnictwo AB, 2015.

Nowak-Dłużewski, Juliusz. Okolicznościowa poezja polityczna w Polsce. Zygmunt III. Warsaw: Instytut Wydawniczy PAX, 1971.

Olkiewicz, Joanna. Kallimach doświadczony. Warsaw: Ludowa Spółdzielnia Wydawnicza, 1981. 
Orzechowski, Stanisław. "Dyjalog abo rozmowa około egzekucyjej Polskiej Korony." In Stanisław Orzechowski, Wybór pism. Edited by Jerzy Starnawski, 304-457. Wrocław: Zakład Narodowy Imienia Ossolińskich - Wydawnictwo, BN I 210, 1972.

Orzechowski, Stanisław. Oksza na Turka. Trans. Jan Januszowski. Krakow: Drukarnia Łazarzowa, 1590.

Orzechowski, Stanisław. "Quincunx." In Stanisław Orzechowski, Wybór pism. Edited by Jerzy Starnawski, 458-619. Wrocław: Zakład Narodowy Imienia Ossolińskich - Wydawnictwo, BN I 210, 1972.

Palczowski, Paweł. Status Venetorum, sive Brevis tractatus de Origine et Vetustate Venetorum. Cracoviae: Officina Lazari, 1604.

“Peregrynacyja do Ziemi Świętej Jana Goryńskiego." In Dwie peregrynacje z XVI wieku. Warsaw: Władysław T. Baranowski, 1914, Prace Komisji do badań nad historią literatury i oświaty, vol. 1, 263-289.

Przyboś, Adam. "Wstęp." In Podróż królewicza Władystawa Wazy do krajów Europy Zachodniej w latach 1624-1625 w świetle ówczesnych relacji. Edited by A. Przyboś, 7-36. Krakow, 1977.

Pyłypenko, Wołodymyr. W obliczu wroga. Polska literatura antyturecka od połowy XVI do połowy XVII wieku. Oświęcim: Napoleon V, 2016.

Quirini-Popławska, Danuta. "Pobyt w Wenecji pielgrzymów udających się do Ziemi Świętej w XIV i XV wieku." In Danuta Quirini-Popławska, Italia Mia. Studia z dziejów Italii i powiazań polsko-włoskich w późnym Średniowieczu i Renesansie, 163-180. Krakow: Towarzystwo Wydawnicze Historia Iagellonica, 2016.

Quirini-Popławska, Danuta. "Podróże polskich duchownych do Padwy w XV i XVI wieku; wstępne rozpoznanie." In Itinera clericorum. Kulturotwórcze i religijne aspekty podróży duchownych. Edited by Danuta Quirini-Popławska and Łukasz Burkiewicz, 225-253. Krakow: Wydawnictwo Naukowe Akademii Ignatianum, 2014.

Quirini-Popławska, Danuta. "Republika Wenecka wobec akcji antytureckiej w latach 1440-1444 na tle sytuacji politycznej w Europie." In Danuta Quirini-Popławska, Italia Mia. Studia z dziejów Italii i powiązan polsko-włoskich w późnym Średniowieczu i Renesansie, 147-160. Krakow: Towarzystwo Wydawnicze Historia Iagellonica, 2016.

Quirini-Popławska, Danuta. “Wenecja jako etap podróży do Ziemi Świętej (XIII-XV w.)." In Peregrinationes. Pielgrzymki w kulturze dawnej Europy. Edited by Halina Manikowska, Hanna Zaremska, 126-143. Warsaw: Instytut Historii Polskiej Akademii Nauk, 1995.

Radziwiłł, Mikołaj K. Peregrynacyja abo Pielgrzymowanie do Ziemie Świętej Jaśnie Oświeconego Pana J[ego] M[ości] P[ana] Mikołaja Chrysztofa Radziwiłła, książęcia na Ołyce i Nieświeżu, hrabie na Szydłowcu i Mir, wojewody wileńskiego, szawelskiego etc. starosty. Przez Jego M[ość] Ks[iędza] Tomasza Tretera, kustosza warmieńskiego, językiem łacińskim napisana i wydana.... Translated by Andrzej Wargocki. Krakow: Szymon Kempinius, 1611.

Rywocki, Maciej. Ksiegi peregrynackie (1584-1587), published by Jan Czubek. Krakow: Nakładem Akademii Umiejętności, 1910. 
S[molik] Jan. "Ad amplissimum Senatum Venetum." In Jan S[molik], Otucha na pogany: wszytkim potentatom chrześcijańskim. Krakow: [Siebeneicher Jakub], 1594.

Sajkowski, Alojzy. Włoskie przygody Polaków. Wiek XVI-XVIII. Warsaw: Państwowy Instytut Wydawniczy, 1973.

Stanislai Resci diarium 1583-1589, edited by Jan Czubek. Archiwum do Dziejów Literatury i Oświaty w Polsce, series I, vol. 15, part 1. Krakow, 1915.

Stryjkowski, Maciej. O wolności Korony Polskiej i Wielkiego Księstwa Litewskiego. Krakow: Mikołaj Szarfenberger, 1575.

Tarnowski, Stanisław. Pisarze polityczni XVI wieku. Introduction and notes Bogdan Szlachta. Krakow: Ośrodek Myśli Politycznej, Księgarnia Akademicka, 2000.

Trafiłowski, Piotr. „Imago Turci”. Studium z dziejów komunikacji społecznej $w$ dawnej Polsce (1453-1572). Lublin: Wydawnictwo Uniwersytetu Marii Curie-Skłodowskiej, 2013.

Tucci, Ugo. I servizi marittimi veneziani per il pellegrinaggio in Terrasanta nel Medioevo. Venice: Università di Venezia, 1991.

Twardowski, Samuel. Ksiażż Wiśniowiecki Janusz. Edited by R. Krzywy. Warsaw: Wydawnictwo Neriton, 2014, Biblioteka Dawnej Literatury Popularnej i Okolicznościowej, vol. 13.

Twardowski, Samuel. Władysław IV, król polski i szwedzki. Published by R. Krzywy. Warsaw: Instytut Badań Literackich Wydawnictwo, Pro Cultura Litteraria, 2012, Biblioteka Pisarzy Staropolskich, vol. 40.

Ulewicz, Tadeusz. Iter Romano-Italicum Polonorum, czyli o zwiazkach umystowo-kulturalnych Polski z Włochami w wiekach średnich i renesansie. Krakow: Universitas, 1999.

Ulewicz, Tadeusz. "Związki kulturalno-literackie Polski z Włochami w wiekach średnich i renesansie. Ogólny szkic panoramiczny." In Literatura staropolska w kontekście europejskim (Zwiazki i analogie). Materiaty konferencji naukowej poświęconej zagadnieniom komparatystyki (27-29 X 1975). Edited by T. Michałowska i J. Ślaski, 21-67. Wrocław: Zakład Narodowy Imienia Ossolińskich - Wydawnictwo Polskiej Akademii Nauk, 1977.

[Warszewicki, Krzysztof.] Wenecyja. [Krakow]: Mateusz Siebeneicher, 1572.

“Wenecja." In Andrzej Wargocki. O Rzymie pogańskim i chrześcijańskim. Księgi dwoje, 137-146. Krakow, 1610.

Wierzbowski, Teodor. "Przedmowa." In Wenecyja. Poemat historyczno-polityczny z końca XVI wieku. Published by Teodor Wierzbowski, I-XLI. Warsaw: Drukarnia Józefa Bergera, 1886.

Zamoyski, Jan. De Senatu Romano libri duo. Venice: Jordano Zileto, 1563.

Zinkow, Leszek. "Wenecja na trasie peregrynacji Mikołaja Krzysztofa Radziwiłła «Sierotki» do Egiptu i Ziemi Swiętej." In Terra Culturae. Obszary, transfery, recepcje kultury. Studia oraz szkice o kulturze i historii. Edited by Łukasz Burkiewicz, 143-156. Krakow: Wydawnictwo Naukowe Akademii Ignatianum, 2018. 
Michał Kuran - University of Lodz, Institute of Polish Philology and Speech-Language Pathology, Department of Old Literature, Editing and Auxiliary Sciences. The author's main focus areas include: celebratory literature, anti-Turkish literature, Old Polish prose. Main publications: Retoryka, historia $i$ tradycja literacka w twórczości okolicznościowej Samuela Twardowskiego, Łódź 2008; Marcin Paszkowski - poeta okolicznościowy i moralista z początku XVII wieku, Łódź 2012.

E-mail: michal.kuran@uni.lodz.pl 